\title{
Article \\ Cement Mortars with Addition of Fly Ash from Thermal Transformation of Sewage Sludge and Zeolite
}

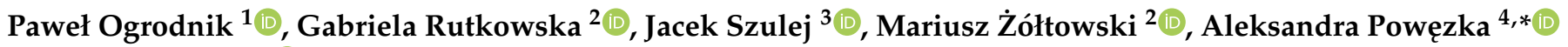 \\ and Artur Badyda 5 (D) \\ 1 Institute of Safety Engineering, The Main School of Fire Service, 52/54 Słowackiego Street, \\ 01-629 Warsaw, Poland; pogrodnik@sgsp.edu.pl \\ 2 Institute of Civil Engineering, Warsaw University of Life Sciences, 166 Nowoursynowska Street, \\ 02-787 Warsaw, Poland; gabriela_rutkowska@sggw.edu.pl (G.R.); mariusz_zoltowski@sggw.edu.pl (M.Ż.) \\ 3 Faculty of Civil Engineering and Architecture, Lublin University of Technology, 40 Nadbystrzycka Street, \\ 20-618 Lublin, Poland; j.szulej@pollub.pl \\ 4 Faculty of Safety Engineering and Civil Protection, The Main School of Fire Service, 52/54 Słowackiego Street, \\ 01-629 Warsaw, Poland \\ 5 Faculty of Building Services, Hydro- and Environmental Engineering, Warsaw University of Technology, \\ 00-653 Warsaw, Poland; artur.badyda@pw.edu.pl \\ * Correspondence: apowezka@sgsp.edu.pl
}

check for updates

Citation: Ogrodnik, P.; Rutkowska, G.; Szulej, J.; Żółtowski, M.; Powęzka, A.; Badyda, A. Cement Mortars with Addition of Fly Ash from Thermal Transformation of Sewage Sludge and Zeolite. Energies 2022, 15, 1399. https://doi.org/10.3390/en15041399

Academic Editor: Francesco Nocera

Received: 29 December 2021

Accepted: 11 February 2022

Published: 15 February 2022

Publisher's Note: MDPI stays neutral with regard to jurisdictional claims in published maps and institutional affiliations.

Copyright: (c) 2022 by the authors. Licensee MDPI, Basel, Switzerland. This article is an open access article distributed under the terms and conditions of the Creative Commons Attribution (CC BY) license (https:// creativecommons.org/licenses/by/ $4.0 /)$.

\begin{abstract}
The aim of research was an influence evaluation of fly ash and zeolite on selected parameters of cement mortar. The scope of the research includes studies of composition and properties of fly ash itself from the thermal transformation of sewage sludge and natural zeolite (clinoptilolite). The research also included the determination of selected mechanical properties of designed mortars, both under normal conditions and after initial thermal loads. A mortar was designed based on CEM I 42.5 $\mathrm{R}$ Portland cement with different content of the applied additive in the amount of 5,10 and $15 \%$ of the cement weight. In the course of experimental work, the bending strength of mortars heated at 20, $300,500,700{ }^{\circ} \mathrm{C}$ were tested. The resulting beam halves $(40 \times 40 \times 160 \mathrm{~mm})$ were used to test the compressive strength. The collected results made it possible to compare the properties of the mortars. The experiment confirmed the possibility of producing cement mortars modified with fly ash from thermal transformation of sewage sludge and zeolite from tuff deposits. The average compressive strength for the mortar containing 5\% fly ash and zeolite was set at 28.7 and $27.1 \mathrm{MPa}$, respectively.
\end{abstract}

Keywords: cement mortars; recycled mortar additives; fly ash; sewage sludge; zeolite

\section{Introduction}

Considering the ingredients used to prepare concrete and mortars, it can be considered that they are environmentally friendly composites. These ecological materials, made of local raw materials-cement, fine aggregate, water, and possibly additives, are sustainable products. One of the most important issues for the development of the construction sector is to make the mortar even more environmentally friendly material. The fact that 0.5 to 1 tons of greenhouse gases are produced during the production of 1 ton of cement is still a big problem [1-4]. Reducing the mortar load is achieved by reducing the consumption of the binder-cement by partially replacing it with another binding additive, or by replacing the standard aggregate with recycled aggregate. In the last few decades, the range of innovative mineral additives used has expanded to include new types of waste and raw materials. Interest in the reuse of by-products from various industries in concrete and mortar technology has increased. Striving to limit natural resources and lower production costs makes it more and more important to use traditional raw materials-waste materials as substitutes.

Economic development, industrialization, and urbanization as well as the rapid growth of the world population require dynamic development of sewage networks. In 
2017, 45 million tons of dry sludge were produced worldwide, the most in China-over 12 million tons, while in the EU the highest annual production was recorded in Germany (1.85 million tons of dry matter), Great Britain (1.14 million tons) and Spain (1.03 million tons). In the United States, China, Norway, Australia, France, Spain, and Great Britain, agriculture is the dominant method of utilizing the generated sewage sludge $[5,6]$. In Poland, Germany, and Austria, the use of sewage sludge in agriculture is limited by the applicable regulations [7], while in Japan $48 \%$ of the total production of sewage sludge is used to produce building materials [8]. The municipal wastewater delivered to the treatment plant is a mixture of industrial wastewater and rainwater (in the case of combined sewage systems or as infiltration waters). Both the composition and the amount of wastewater flowing into the treatment plant change in the annual, monthly, weekly, and daily cycles [9]. The choice of the generated sewage sludge utilization method includes the content of the main components such as silicon (IV) oxide $\left(\mathrm{SiO}_{2}\right)$, aluminum (III) oxide $\left(\mathrm{Al}_{2} \mathrm{O}_{3}\right)$, calcium (II) oxide $(\mathrm{CaO})$, iron (III) oxide $\left(\mathrm{Fe}_{2} \mathrm{O}_{3}\right)$, sulfur $(\mathrm{VI})$ oxide $\left(\mathrm{SO}_{3}\right)$ and phosphorus $(\mathrm{V})$ oxide $\left(\mathrm{P}_{2} \mathrm{O}_{5}\right)$ as well as heavy metal content [10-12]. In Europe, the most popular method of sludge disposal is incineration. The thermal process consists of burning the sewage sludge generated in boilers (fluidized bed, rotary, grate), co-firing with other fuels, pyrolysis or gasification. Thermal combustion in a fluidized bed boiler is a popular method [10-12]. The advantages are the reduction of sludge, the production of heat, electricity, and the reduction of sulfur and nitrogen compounds in the exhaust gas. Nevertheless, the waste material in installations for thermal treatment of sewage sludge is fly ash (waste) with the code 1901 14 [13]. The basic legal act regulating the issues of waste thermal treatment, including the incineration of municipal sewage sludge with energy recovery is 2010/75/EU directive of the European Parliament and Council on industrial emissions. The purpose of these provisions is to prevent, or reduce negative effects on the environment, in particular pollution through emissions risks to human health caused by the incineration and co-incineration of waste [14]. The waste (fly ash from thermal treatment of sewage sludge-SSA) that is the subject of this study is not defined in any source of law, except for the footnotes included in the waste catalog with a general code. Following the principle of the similarity of individual features to other fine-grained materials used in construction, an analysis of the directions of use of fly ash generated from sewage sludge was carried out. The analogy to the used ash from coal combustion for which the standards and numerous studies indicating the legitimacy of their use was considered [15].

Research is conducted on the possibility of using this type of waste as a source of phosphorus [16-19], in construction [20-23], or in mining technologies [24,25]. Due to the variety of research presented in the publications, this article presents research related to the use of SSA in cement materials.

In the research of Monzo and Merino on cement mortars, the hydraulic binder was replaced in the amount of $15-30 \%$ with fly ash from sediments. Based on obtained results, it is known that the mortar containing $15 \%$ ash is characterized by comparable compressive strength. The content of the additive can be increased to $30 \%$ of the cement mass by using additional procedures such as: sample care at elevated temperature or grinding the ash before introducing it into the mortar. Additionally, it was found that replacing the cement with fly ash deteriorates the workability of the mix. This can be explained by the high water demand and irregular structure of individual ash grains from sewage sludge [26,27].

In the studies of Baeza-Brotons et al. Fly ash in the amount of 5, 10, 15, 20\% was introduced into the concrete blocks. The tests on the blocks after 28 days of maturation showed comparable mechanical properties to the reference blocks without additive. blocks in which sand was replaced with $10 \%$ of fly ash showed the best properties such as capillarity, absorption and density [28]. These results confirm previous studies by Chang [29].

Chen et al. assessed the possibility of using sludge ash as a substitute for sand or cement. Concretes and mortars made with ash showed lower compressive and bending strengths compared to traditional composites. It was proved that mortars containing up to $10 \%$ of the additive achieve similar compressive strength to conventional mortars. 
Considering the studies of heavy metals leaching, it was found that the concentrations of pollutants of harmful elements do not exceed the threshold values given by the Environmental Protection Agency. The use of SSA fly ash seems possible [30].

Research presented by Suchorab et al. has shown that we can use sewage sludge as an additive to produce lightweight aggregates and can then be used to produce lightweight concretes. As shown, this additive has a positive effect on the thermal parameters of the aggregates produced, which improves the energy efficiency of buildings [31].

In the work of $\mathrm{Qu}$, the influence of elevated temperature on the mechanical behavior of geopolymer mortars after the initial load-induced damage was investigated. Mortars with different contents of fly ash (granulated blast furnace slag-GGBFS) were prepared for the tests. The results show that before the exposure to high temperature, the GGBFS additive increased the compressive strength of GSM, leading to increased strength loss. GSM showed lower residual strength after exposure to high temperatures and preload. Compared to the PCM, GSM with GGBFS performed better at $300^{\circ} \mathrm{C}$, while its performance deteriorated due to severe damage from 500 and $700{ }^{\circ} \mathrm{C}$.

Khan describes the behavior of fly ash concrete when exposed high temperature. A concrete mix (1:2.37:2.98) with $340 \mathrm{~kg} / \mathrm{m}^{3}$ cement and $\mathrm{w} / \mathrm{c}$ ratio 0.45 was prepared. Cement was replaced percentages with fly ash in the amount of $0,20,40,50$, and $60 \%$ by weight of cement. The concrete was heated at the temperature of $200{ }^{\circ} \mathrm{C}$ for $7,14,21$, and 28 heating cycles. The cyclic thermal load increase the compressive strength, while the thelmal conductivity of the concrete composite decreases with the increase in the fly ash content [32,33].

Zeolites are natural volcanic minerals with many unique properties. Created because of the volcanic ashes deposition in former alkaline lakes. An additive in the form of clinoptilolite, a mineral from the group of silicates belonging to the zeolite group, was applied to the base mixture.

The main features of zeolite, thanks to which it is used on such a wide scale, are selectivity, adsorption, and ion exchange capacity, molecular-sieve ability to withstand high temperature, and acid action. A very important advantage of zeolite is the possibility of its modification.

Clinoptilolite, due to its sorption and ion exchange properties, is successfully used, for example, in agriculture, environmental protection, and construction. Macroscopically, it is a gray, fine-grained rock with small dark biotite plaques visible in places. Microscopically, it has a compact, weakly bonded, inert, fluidized texture in places.

Much research literature is devoted to zeolites, which are components of binders for special applications [34-37]. Clinoptilolite is a valuable natural pozzololite additive to produce concrete, which was confirmed in Refs. [38,39]. Vrjmrlkova [40] showed a beneficial effect of replacing $10 \%$ cement with zeolite due to the transport of water and water vapor in concrete-it is important during heating at high temperatures. The research by Grabowska [41] shows that the addition of zeolite increases the resistance to sulphate corrosion. The cause of the beneficial effect is the pozzolanic properties and the related changes in the phase composition of the slurry consisting of limiting the amount of calcium hydroxide.

The aim of the research work was to assess the possibility of rational use of fly ash from the thermal transformation of sewage sludge and natural zeolite (clinoptilolite) as a cement substitute in the production of mortars. The basic physical properties of the additives used were investigated. The tests determined the effect of the applied mortar additives on their bending strength under compression under normal conditions and after initial thermal load. The influence of elevated temperatures on the mechanical properties of the designed mortars was also determined.

The annealing temperatures were chosen for the conditions occurring in various stages of a fire occurring in rooms at different heights. It is important due to the possibility of damaging the cladding and, consequently, reducing the load-bearing capacity of structural elements of building structures. The temperatures selected for the tests are also characterized by characteristic points where structural changes occur in the mortars. The samples 
were heated in accordance with the adopted temperature distribution curve, similar to the so-called standard curve used to test the fire resistance of structural elements of buildings.

\section{Materials and Methods}

\subsection{Cement Mortar}

For the preparation of cement mortars, CEM I 42.5 R Portland cement (Cement Ożarów SA, Ożarów, Poland), fine aggregate with a grain size of 0-2 mm (Kwarcmix, Tomaszów Mazowiecki, Poland), water, and an additive in the form of fly ash from thermal sludge treatment were used wastewater from the "Płaszów" sewage treatment plant in Cracow (Płaszów II Sewage Treatment Plant, Cracow, Poland) or clinoptilolite, obtained from the deposits of zeolite tuffs from the Sokyrnytsya mine (Sokyrnytsya, Zakarpatia Oblast, Ukraine).

In order to determine the effect of the additive, in the form of fly ash and zeolite, on the bending strength under compression, three types of samples were prepared:

- MC—no additive-standard mortar;

- $\mathrm{MCF}$ - with the addition of fly ash from thermal treatment of sewage sludge in the amount of 5, 10 and $15 \%$ of the cement mass;

- MCZ-with the addition of zeolite in the amount of 5, 10 and 15\% of the cement mass.

Table 1 shows the composition of each cement.

Table 1. Cement mortar proportions by weight.

\begin{tabular}{ccccc}
\hline \multirow{2}{*}{ Specification } & \multicolumn{4}{c}{ Mass of Cement Mortar Ingredients [g] } \\
\cline { 2 - 5 } & Aggregate & Water & Cement & Fly Ash/Zeolite \\
\hline MC & 1350.0 & 225.0 & 450.0 & - \\
MCF/MCZ 5\% & 1350.0 & 225.0 & 427.5 & 22.5 \\
MCF/MCZ 10\% & 1350.0 & 225.0 & 405.0 & 45.0 \\
MCF/MCZ 15\% & 1350.0 & 225.0 & 382.5 & 67.5 \\
\hline
\end{tabular}

\subsection{Cement}

All samples were made based on CEM I 42.5 R cement (Cement Ożarów S.A., Ożarów, Poland). The declared performance properties of Portland cement, class 42.5 and high early strength (R) are summarized in Table 2 . The given values are average values guaranteed by the manufacturer for 2020.

Table 2. Mechanical, chemical, and physical parameters [42].

\begin{tabular}{ccc}
\hline Parameters & $\begin{array}{c}\text { Standard Requirements } \\
\text { PN-EN 197-1 }\end{array}$ & Average Values Achieved \\
\hline Compressive strength [MPa] & & \\
after 2 days & $\geq 20$ & 29.9 \\
after 28 days & $\leq 52.5 \leq 62.5$ & 56.6 \\
Loss on ignition [\%] & $\leq 5.0$ & 2.98 \\
The residue is insoluble [\%] & $\leq 4.0$ & 0.77 \\
Sulphate content $\mathrm{SO}_{3}[\%]$ & $\leq 0.10$ & 3.22 \\
Chloride content $\mathrm{Cl}^{-}[\%]$ & $\geq 60$ & 0.05 \\
Start of setting time [min] & $\leq 10$ & 196 \\
Consistency [mm] & no requirements & 0.5 \\
Specific surface $\left[\mathrm{cm}^{2} / \mathrm{g}\right]$ & & 4138 \\
\hline
\end{tabular}

\subsection{Methodology of Fly Ash and Zeolite Testing}

To find out about the physical and chemical properties of fly ash, tests were performed from thermal treatment of sewage sludge and zeolite. The ash grain size distribution analysis was measured in a Mastersizer 3000 analyzer (Malvern Panalytical, Malvern, UK) based on laser diffraction. The measurement was carried out as an ultrasonic probe in a dispersing liquid (demineralized water) to break up larger aggregates of tested samples. 
Grains with a diameter from 0.1 to $1000 \mu \mathrm{m}$ were analyzed. The chemical composition and morphology in the micro-area were determined using the SEM Quanta 250 FEG microscope (Panalytical, Eindhoven, the Netherlands), equipped with a chemical composition analysis system (EDAX, AMETEK Inc., Berwyn, IL, USA). The chemical composition of the tested fly ash was determined by the energy dispersive X-ray fluorescence (XRF) method. (Panalytical, Eindhoven, The Netherlands). The test was carried out in the measuring range of sodiumamericium (Na-Am) using an apparatus equipped with an X-ray tube Rh $9 \mathrm{~W}, 50 \mathrm{kV}$, $1 \mathrm{~mA}, 4096$ channel spectrum analyzer, 6 measurement filters (Cu-500, Cu-300, Ti, Al-50, Al-200, Ag) and a high-resolution semiconductor SDD detector (Panalytical, Eindhoven, Netherlands) (Be window, $50 \mu \mathrm{m}$ thick) cooled with a Peltier cell. The mineral composition was determined using the X-ray phase XRD analysis. Measurements were made using the powder method, with use of Panalytical X'pertPRO MPD X-ray diffractometer with a PW 3020 goniometer (Panalytical, Eindhoven, the Netherlands). The X'Pert Highscore software (Panalytical, Eindhoven, Netherlands) was used to process the diffraction data. The identification of mineral phases was based on the PDF-2 JCPDS-ICDD database.

To assess the effect of fly ash from thermal transformation of sewage sludge and zeolite on the properties of cement mortars produced with their participation, the bending strength was tested in accordance with the PN-EN 12390-5 standard after 28 days [43]. The test was carried out on cuboidal samples with dimensions of $40 \times 40 \times 160 \mathrm{~mm}$, which were placed horizontally between the breaking supports. The bars were bent with increasing load until they were destroyed. A single-point load scheme has been adopted. The halves of the bars formed after the test were used for the compressive strength test. The Controls Advantest 9 hydraulic press (Controls, Warsaw, Poland) was used for the conducted test.

\subsection{Thermal Load and Properties of Cement Mortars}

The cement mortar samples were annealed at $20,300,500$ and $700{ }^{\circ} \mathrm{C}$ in a PK $1100 / 5$ furnace (Thermolab SC, Warsaw, Poland) powered by electricity. During the tests, efforts were made to ensure that the temperature distribution over time was similar to the conditions corresponding to the real fire. The thermal distribution in the elements is described according to PN-EN 1363-1. The temperature was monitored with a thermocouple [44].

Annealing was carried out on bars $40 \times 40 \times 160 \mathrm{~mm}$, intended for testing the bending and compressive strength, with the number of tests amounting to 7 samples. The elements were heated in accordance with the standard temperature-time curve for a given combination of loads at each time. The temperature distribution in the bars is shown in Figure 1.

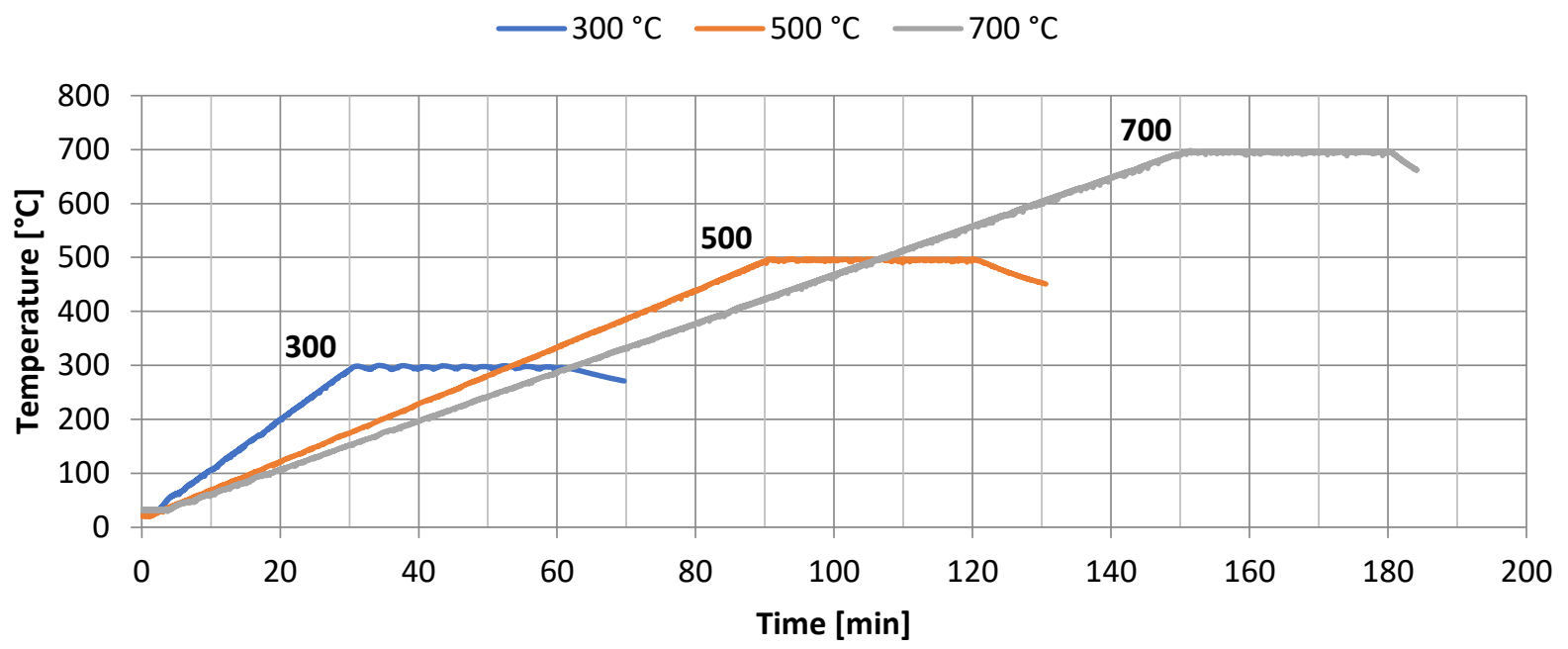

Figure 1. Temperature distribution in the elements.

The analysis of temperature influence on the elements made of the designed cement mortars was carried out over a specified period, without the cooling phase. After reaching 
the assumed temperature, i.e., $20,300,500$, and $700{ }^{\circ} \mathrm{C}$, the samples were annealed for another $30 \mathrm{~min}$. It was aimed at equalizing the temperature in the entire volume of the element, and then it was freely cooled to the ambient temperature. The total time of loading the element with the temperatures of 300,500 , and $700{ }^{\circ} \mathrm{C}$ was, respectively, for mortars-60, 120, $180 \mathrm{~min}$. Then the samples were tested for selected mechanical properties.

Under the influence of thermal load, the Portland cement slurry decomposes the phase $\mathrm{C}_{4} \mathrm{AH}_{13}\left(170-180{ }^{\circ} \mathrm{C}\right)$ and calcium monosulfate $\left(190-200{ }^{\circ} \mathrm{C}\right)$, and the $\mathrm{C}_{3} \mathrm{AH}_{6}$ loses water $\left(340{ }^{\circ} \mathrm{C}\right)$. At a temperature of $500-550{ }^{\circ} \mathrm{C}$ decomposes to $\mathrm{Ca}(\mathrm{OH})_{2}$. The decomposition of $\mathrm{CSH}$ phases occur gradually and is related to the discharge of water, while the final degree of decomposition occurs at a temperature of about $750{ }^{\circ} \mathrm{C}$ [45-47].

\subsection{The Statistical Methods Used}

In order to study and describe the obtained statistical population, to gather as much knowledge as possible from the obtained data, and to determine the basic patterns and trends, a statistical analysis was carried out. Calculated basic statistics such as mean, sample standard deviation.

The Statiscica 2020 version 2.0 software package (TIBCO Software Inc., Palo Alto, CA, USA) made it possible to carry out further analyzes from the received data. It was checked whether the value of the $t$ (t-Student) statistic indicates a statistically significant correlation between the observed and discussed differences between the mean values of the tested strength characteristics. For this purpose, the t-Student test was performed for independent samples, two different groups (samples) of observations were compared with each other. The null hypothesis of the test is: $H_{0}$ : there are no significant differences between the data groups $\left(\beta_{i}=\beta_{i}\right)$, and the alternative hypothesis $H_{1}$ : there is a difference between the groups $\left(\beta_{i} \neq \beta_{i}\right)$. If the obtained implementation of the test statistic falls into the critical area-we reject $H_{0}$-then we take $H_{1}$. If the obtained realization of the test statistic does not fall into the critical area-there are no grounds for rejecting $H_{0}$.

In order to predict the compressive/flexural strength of the obtained cement mortars with the addition of zeolite/fly ash, a regression model was built, described by a continuous function of a given algorithm in the form of a multilayer neural network. A total of 4 prognostic models, one for a given endurance group, were calculated. Input independent variables, i.e., temperature and percentage zeolite/fly ash content, and the dependent variable (compressive/flexural strength, which is the result of the calculations performed, visible on the last output layer, were adopted as predictors. As a result of the calculations, 5 networks with the lowest errors in learning and testing were selected) and validation The interactive relationships between the three variables are shown in categorized $3 \mathrm{~W}$ plots.

\section{Results and Discussion}

\subsection{Fly Ash}

Fly ash resulting from sewage sludge thermal treatment is a dry material with a characteristic red-pink color (Figure 2), which distinguishes it from power industry ash, the color of which oscillates in the gray scale.

Fly ash from thermal treatment of sewage sludge contains, among others: silicon (IV) oxide, iron (III), phosphorus (V), and calcium (II) oxide. The largest percentage of the ash was $\mathrm{SiO}_{2}(32.21 \%), \mathrm{Fe}_{2} \mathrm{O}_{3}(19.25 \%), \mathrm{P}_{2} \mathrm{O}_{5}(18.91 \%)$, and $\mathrm{CaO}(18.64 \%)$. It was observed that the sum of the oxide content of $\mathrm{Fe}_{2} \mathrm{O}_{3}, \mathrm{Al}_{2} \mathrm{O}_{3}$, and $\mathrm{SiO}_{2}$ in the used fly ash was at the level of $57.71 \%$ (the requirements of PN-EN $450-1$, which say about $65 \%$ of the oxide content, are not met). In the basic ash composition, $\mathrm{Al}_{2} \mathrm{O}_{3}(6.25 \%), \mathrm{CaO}(11.9 \%)$, and $\mathrm{MgO}(3.10 \%)$ were determined. Fly ash from sewage sludge contains a lower proportion of $\mathrm{SO}_{3}$ oxide $(2.57 \%)$ compared to ash from the combustion of hard coal and lignite (approx. 4\%). The ignition loss, which shows the content of unburned carbon in the tested sample in a fluidized bed furnace at a temperature above $850{ }^{\circ} \mathrm{C}$, was only $0.5 \%$. According to the research, the low loss of ignition and the phosphate ions present in the fly ash affect the compressive strength of mortars based on this additive [48-50]. 


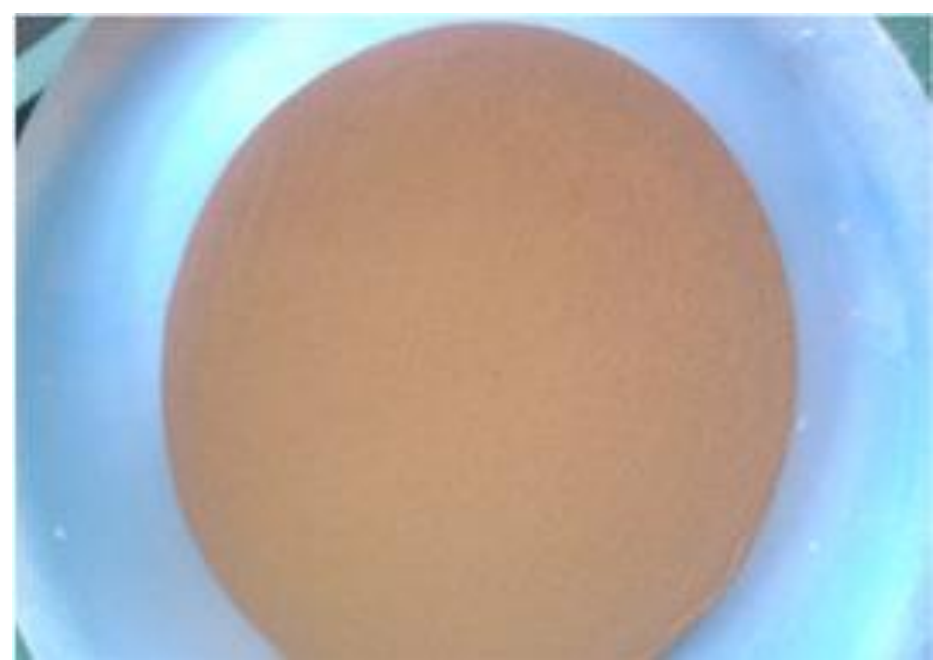

Figure 2. Fly ash from thermal treatment of sewage sludge.

The analysis of oxide composition is presented in Figure 3.

— content of oxides oxides content (\%)

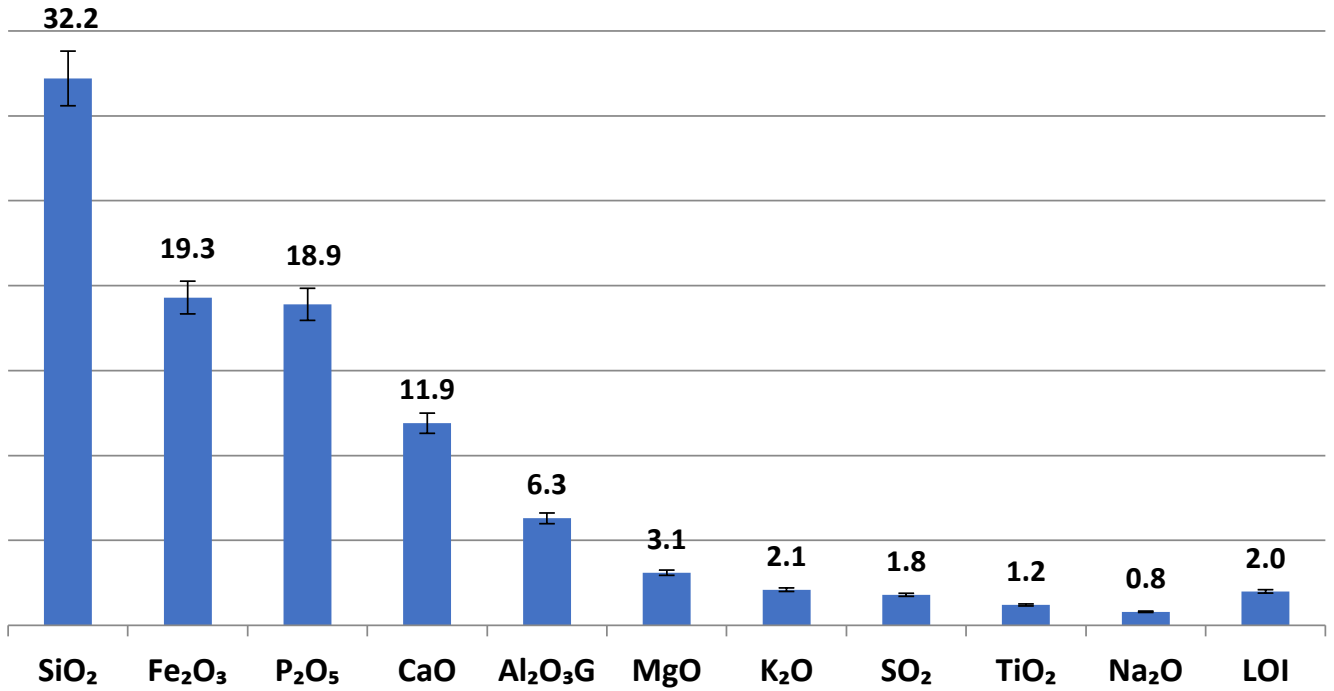

Figure 3. Oxide composition of fly ash from thermal treatment of sewage sludge.

A large amount of $\mathrm{P}_{2} \mathrm{O}_{5}$ is related to the type of sewage supplied to the treatment plant. In the case of ashes from coal combustion, the content is less than $5 \%$ [51,52]. This means that the fly ash from the sediment does not meet the requirement for the content of soluble phosphorus compounds, not more than $\mathrm{mg} / \mathrm{kg}$ of ash. The addition of ash slows down the cement hydration process. Cement containing an increased amount of soluble phosphate compounds binds slower [46,53].

In the SEM microscopic image (Figure 4), we observe grains of irregular shape and different sizes $(2-250 \mu \mathrm{m})$. This heterogeneity may affect the results of the EDS analysis. Measurements were carried out at the marked two points. The spectra are shown in Figure 5.

Chemical analysis in SEM micro-area of tested fly ash sample, as expected by the EDS probe, showed the grains with the chemical composition of the following elements: calcium $(\mathrm{Ca})$, aluminum $(\mathrm{Al})$, iron $(\mathrm{Fe})$, phosphorus $(\mathrm{P})$ and potassium $(\mathrm{K})$, magnesium $(\mathrm{Mg})$ and sodium $(\mathrm{Na})$. 


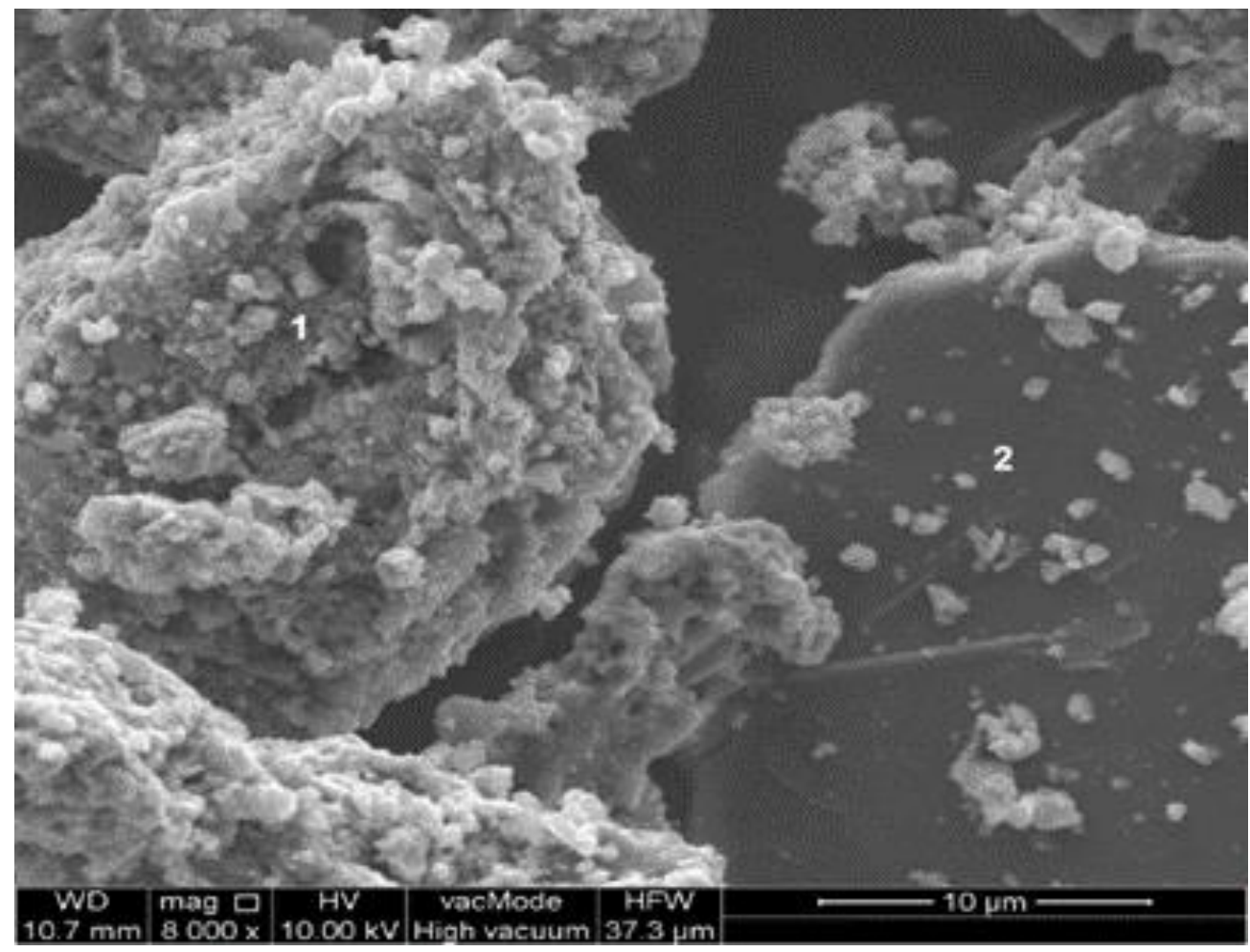

Figure 4. SEM morphology of fly ash.

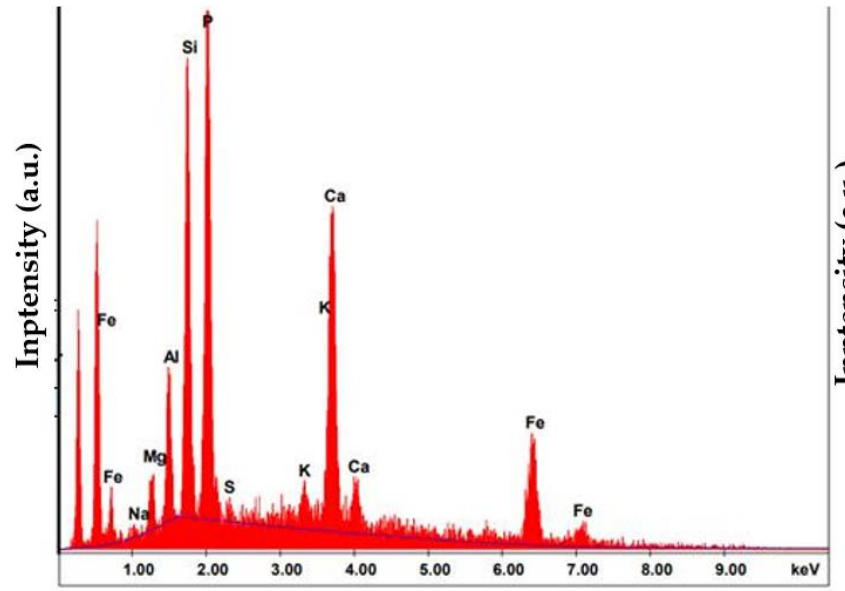

(a)

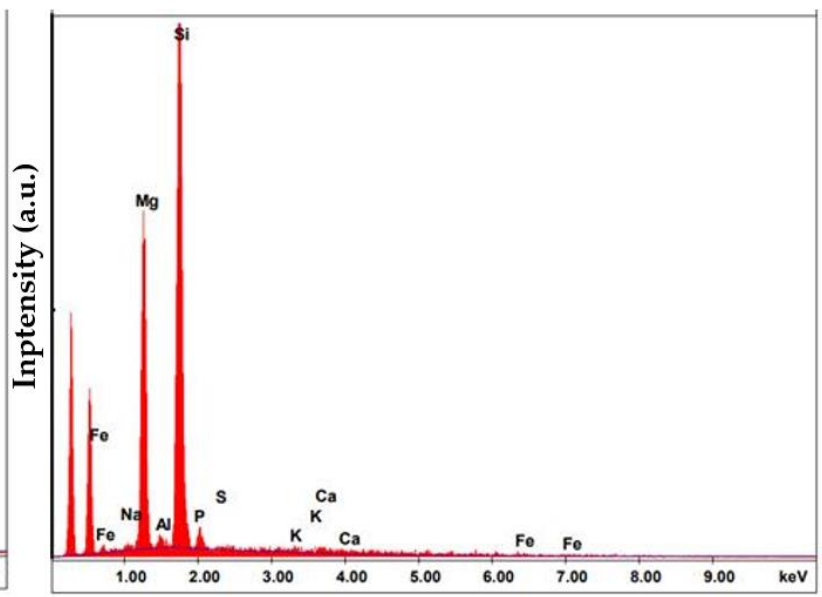

(b)

Figure 5. EDS analysis of fly ash (Figure 3): (a) in point 1 ; (b) in point 2.

The distribution of particle fractions of additive used is shown in Figure 6. The largest percentage share above $25 \%$ were grains with a diameter of 20-250 $\mu \mathrm{m}$, while the smallest, $1.45 \%$, were grains with a diameter of $0.01-2.0 \mu \mathrm{m}$.

Considering the mineral composition of ash from sewage sludge, hematite, quartz and anhydrite dominated, shown in Figure 7 . Minerals were identified by the interplanar characteristics of the distances $d_{h k l}$ for quartz $(4.25 ; 3.34 ; 2.23 ; 2.04 \AA)$, anhydrite $(3.49 ; 2.84$; $2.33 ; 2.21 \AA$ ). $\mathrm{SO}_{3}$ oxide content it is relatively low. The mineral composition of the ashes is complemented by phosphates occurring in form of apatite $\left(\mathrm{d}_{\mathrm{hkl}}=3.40 ; 2.77 ; 2.69 ; 2.61 \AA\right.$ ), and fluoroapatite $\left(\mathrm{d}_{\mathrm{hkl}}=3.43 ; 2.81 ; 2.77 ; 2.70 \AA\right)$. High intensification of anhydrite peaks may result from coincidences associated with apatite and fluoroapatite lines. These mineral phases are mainly $\mathrm{P}_{2} \mathrm{O}_{5}$ solids found in higher amounts than in conventional ashes. 


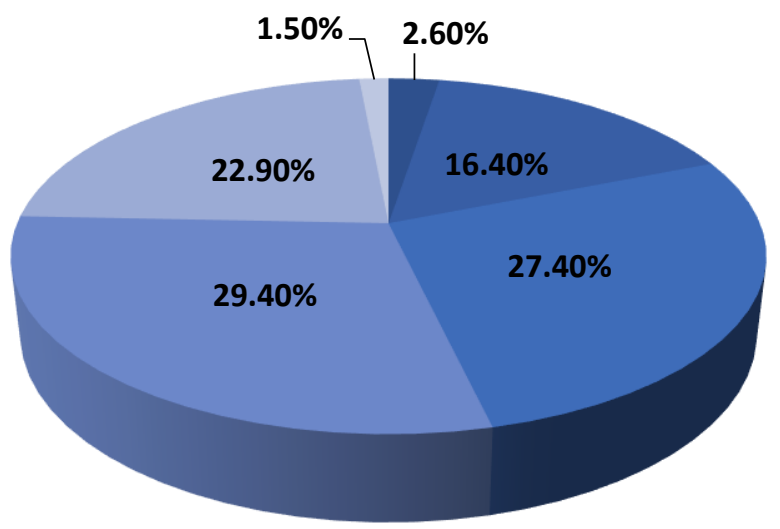

\section{Fraction $[\mu \mathrm{m}]$}

20-50 $\square$ 50-100 $\square$ 100-250

$250-500$

Figure 6. Volumetric distribution of fly ash from thermal treatment of sewage sludge fractions.

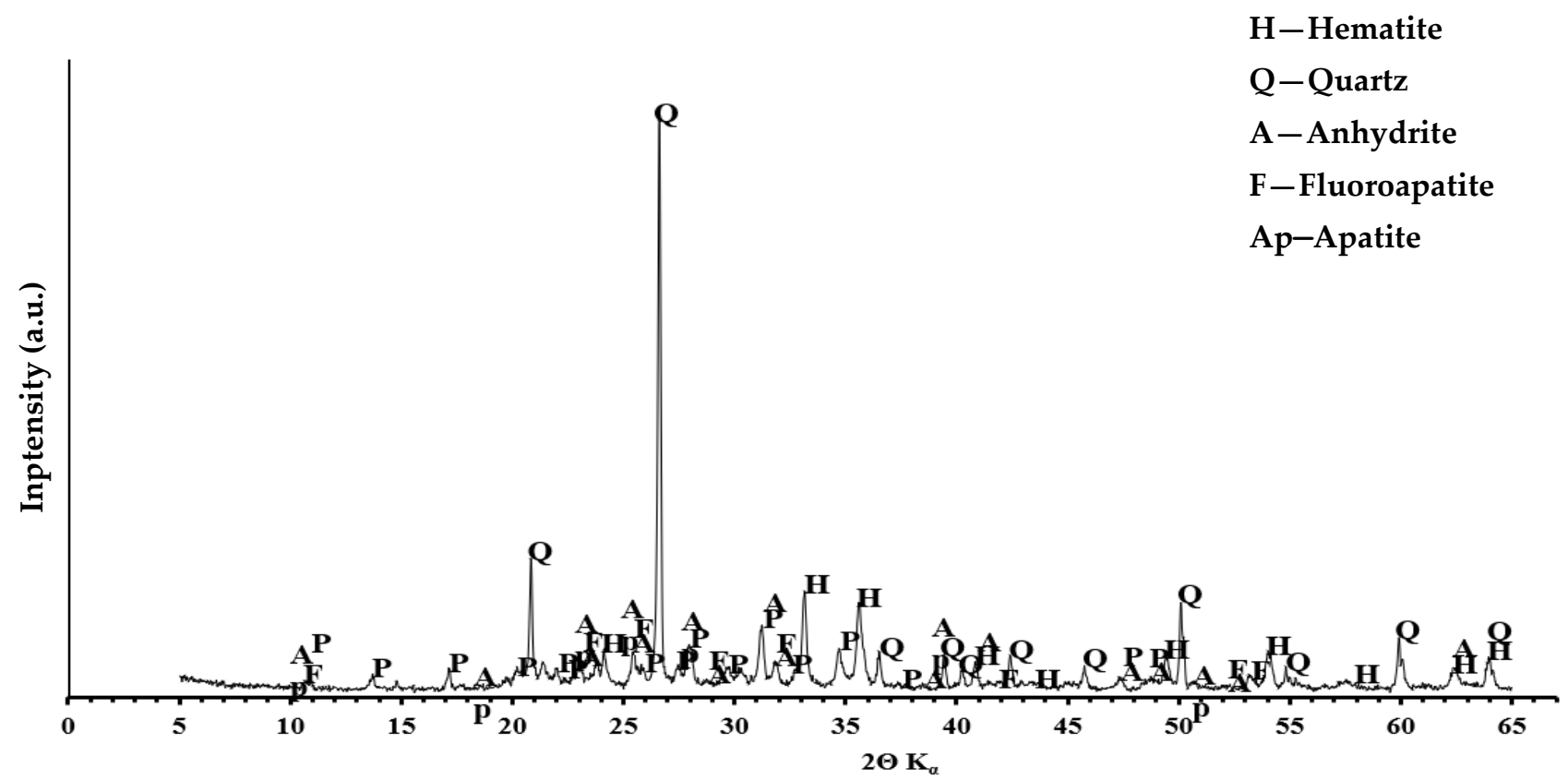

Figure 7. Mineral composition of XRD.

The ash from sewage sludge fineness was determined according to PN-EN 451-2 It was 50.7\%, and the apparent density was tested according to EN 1097 to 1007, and was $2534 \mathrm{~kg} / \mathrm{m}^{3}[54,55]$.

\subsection{Zeolite}

The zeolite microstructure is shown in Figure 8. Clinoptilolite occurs in form of thin plates $25-30 \mu \mathrm{m}$ in size, sometimes with a hexagonal shape. In the phase composition of zeolite clinoptilolite dominates as the main mineral in the amount of approx. $75 \%$. The mineral composition of tuff is complemented by small amounts of CT opal, quartz, potassium feldspar, biotite, illite and smectite.

The chemical composition is dominated by the oxide: $\mathrm{SiO}_{2}, \mathrm{Al}_{2} \mathrm{O}_{3}$, forming the skeleton of the clinoptilolite structure, which is formed by $\mathrm{CaO}, \mathrm{K}_{2} \mathrm{O}, \mathrm{MgO}$ and $\mathrm{Na}_{2} \mathrm{O}$ acting as ion exchange cations compensating for the excess charge of the skeleton. The chemical composition of clinoptilolite is shown in Table 3. Zeolites have a chemical composition similar to that of fly ash. 


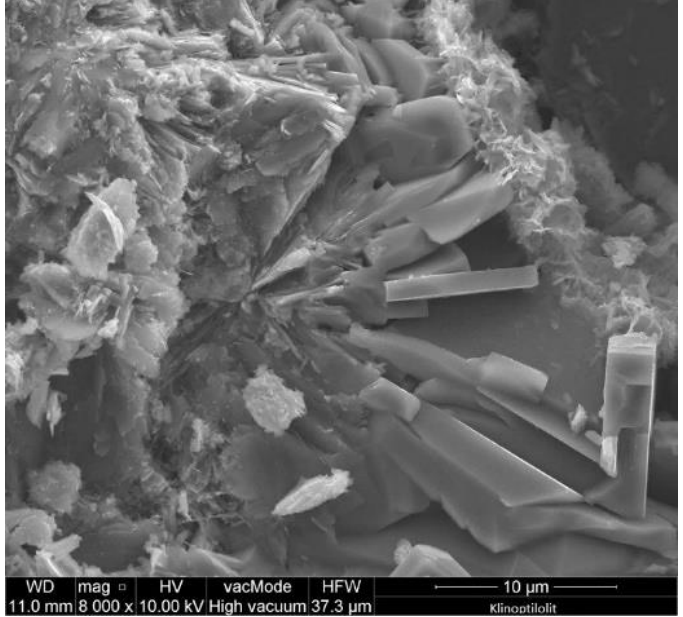

(a)

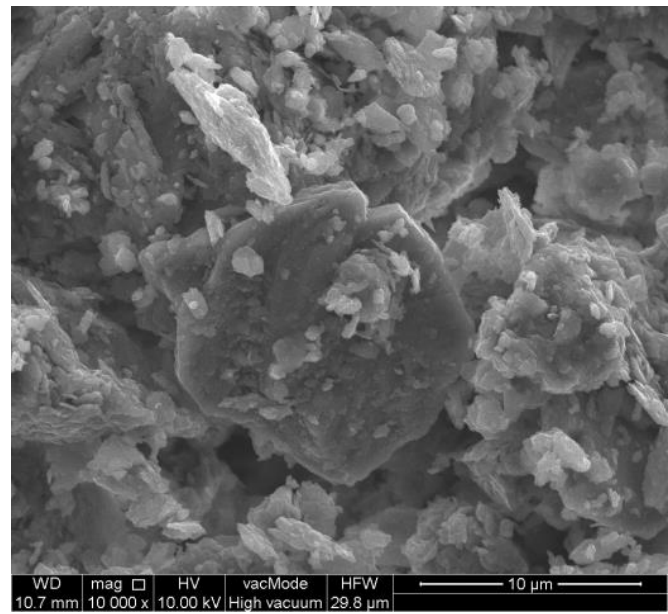

(b)

Figure 8. Image of clinoptilolite grains microstructure, view of thin plates: magnification (a) 8000; (b) 10,000 times.

Table 3. Zeolite composition used in the research.

\begin{tabular}{lcccccc}
\hline Chemical Compound & $\mathrm{SiO}_{2}$ & $\mathbf{A l}_{2} \mathbf{O}_{3}$ & $\mathbf{C a O}$ & $\mathbf{K}_{\mathbf{2}} \mathbf{O}$ & $\mathbf{M g O}$ & $\mathbf{N a}_{\mathbf{2}} \mathbf{O}$ \\
\hline Percentage share [\%] & 68.02 & 12.92 & 3.71 & 3.36 & 0.75 & 0.69 \\
\hline
\end{tabular}

Zeolite material is characterized also by the value of a specific surface area, which for clinoptilolite is $18.3 \mathrm{~m}^{2} / \mathrm{g}$ and is about 50 times greater than the specific cement surface area. Due to the fact that a decisive part in the surface developed, mesopores have $10.65 \mathrm{~m}^{2} / \mathrm{g}$, based on the micropores which size is $7.68 \mathrm{~m}^{2} / \mathrm{g}$. This material represents a texturally mesoporous material. The zeolite density is $2.4 \mathrm{~g} / \mathrm{cm}^{3}$.

The mineral composition of zeolite is dominated by clinoptilolite and quartz. The diffractogram of the mineral composition of this rock is shown in Figure 9. Clinoptilolite was identified by the interplanar characteristics, the distances $d_{\mathrm{hkl}}=8.95,7.94,3.96,3.90$.

The bimodal grain clinoptilolite size distribution is shown in Figure 10. The composition is dominated by zeolite particles ranging in size from 10 to $100 \mu \mathrm{m}$ with a maximum of $25 \mu \mathrm{m}$ (about 19\%). The second particle size range is from 100 to $1000 \mu \mathrm{m}$ with the largest share of $300 \mu \mathrm{m}$ particles (about $23 \%$ ).

\subsection{Properties of Cement Mortar with the Addition of Fly Ash}

The results are the arithmetic mean obtained from 7 measurements and are presented in Figure 11. The beam halves obtained after the test used for the determination of average compressive strength from 14 measurements. The results are shown in Figure 12. Error bars with a value of $5 \%$ are marked in the bar charts.

The results of samples tests containing fly ash from sewage sludge show the highest values of bending strength $(8.6 \mathrm{MPa})$ and compression $(46.9 \mathrm{MPa})$ relating to the base samples not subjected to annealing, showing the highest standard deviation (1.044 and $4.308 \mathrm{MPa}$ ) of the results obtained. After annealing the samples at the temperature of $300{ }^{\circ} \mathrm{C}$, the highest values of flexural and compressive strength were presented by $5 \mathrm{MCF}$ series samples. In their case, there was a 29 and 33\% increase in bending and compressive strength compared to the base samples. A similar situation occurred after the samples were annealed at a temperature of $500{ }^{\circ} \mathrm{C}$, where the $5 \mathrm{MCF}$ series samples obtained a $59 \%$ increase in compressive strength and as much as $67 \%$ increase in bending strength. After annealing the samples at the temperature of $700{ }^{\circ} \mathrm{C}$, most of the samples were damaged, hence only partial results of the compressive strength. The obtained results confirm the positive effect of the application of the fly ash addition. It is reported in the literature that $[40,43]$ the optimal amount of fly ash from the thermal treatment of sewage sludge was from 5 to $20 \%$. 
As shown in Figure 13 in the first test point, after exposure to a temperature of $300{ }^{\circ} \mathrm{C}$, an increase of the factor by 1.0 was observed for the mortar based on $15 \%$ fly ash addition. As shown in the figure, the bending strength decreases as a result of the progressive drainage of the matrix. Nevertheless, the strength of all mortars at a temperature of $800{ }^{\circ} \mathrm{C}$ tends to be 0 .

Figure 14 shows the values of the average compressive strength as a function of temperature. The strengthening effect is visible for mortars heated at $300{ }^{\circ} \mathrm{C}$ with $10 \%$ fly ash content and amounts to 1.4 .

Performing the calculations by the neural network method (Figure 15), the results were Table 4 with a list of active neural networks and their parameters.

Table 4 presents the calculation results of the SANN MLP 2-3-1 model for mortars with the addition of fly ash. They are correct prognostic models due to the quality of learning, testing, and validation close to unity.

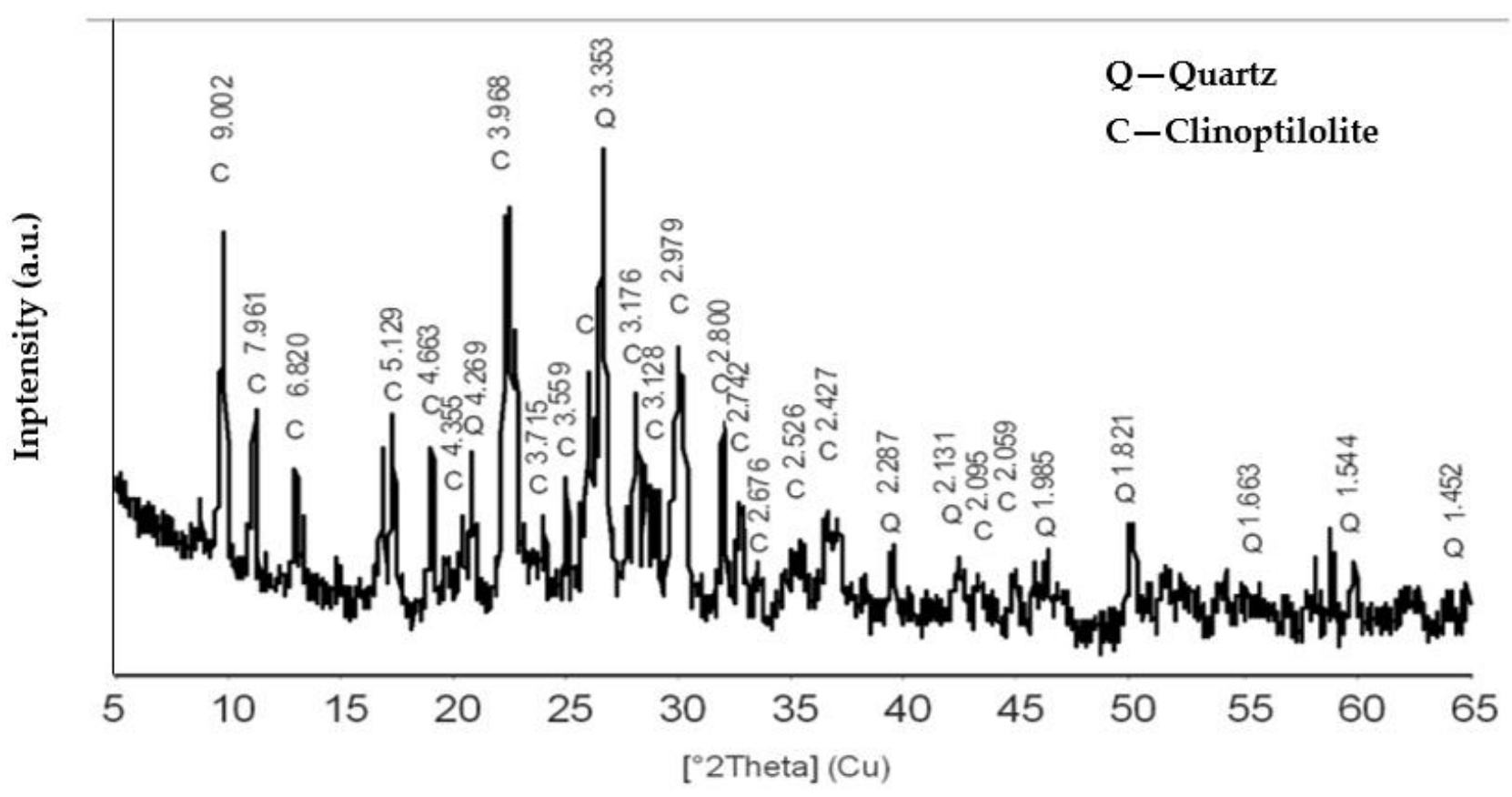

Figure 9. XRD mineral composition of zeolite tuff.

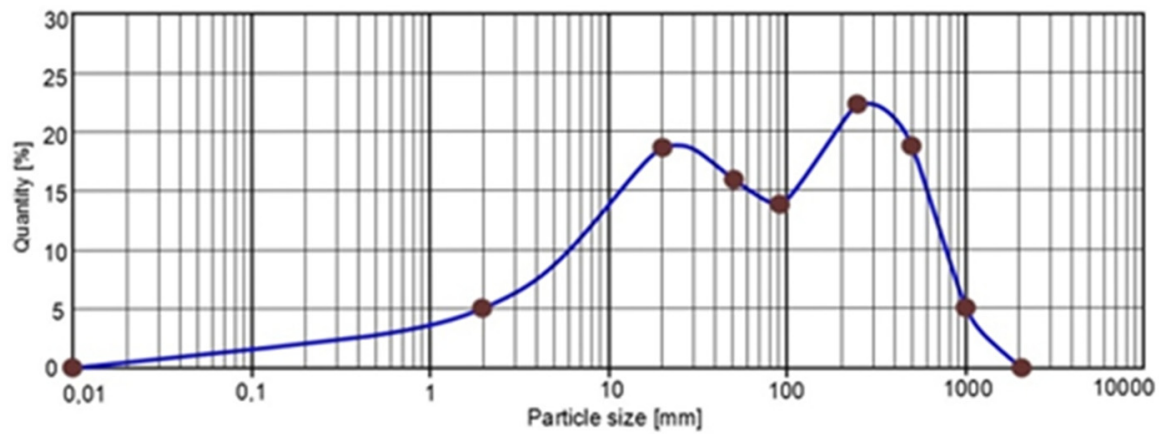

Figure 10. Bimodal grain size distribution of clinoptilolite. 


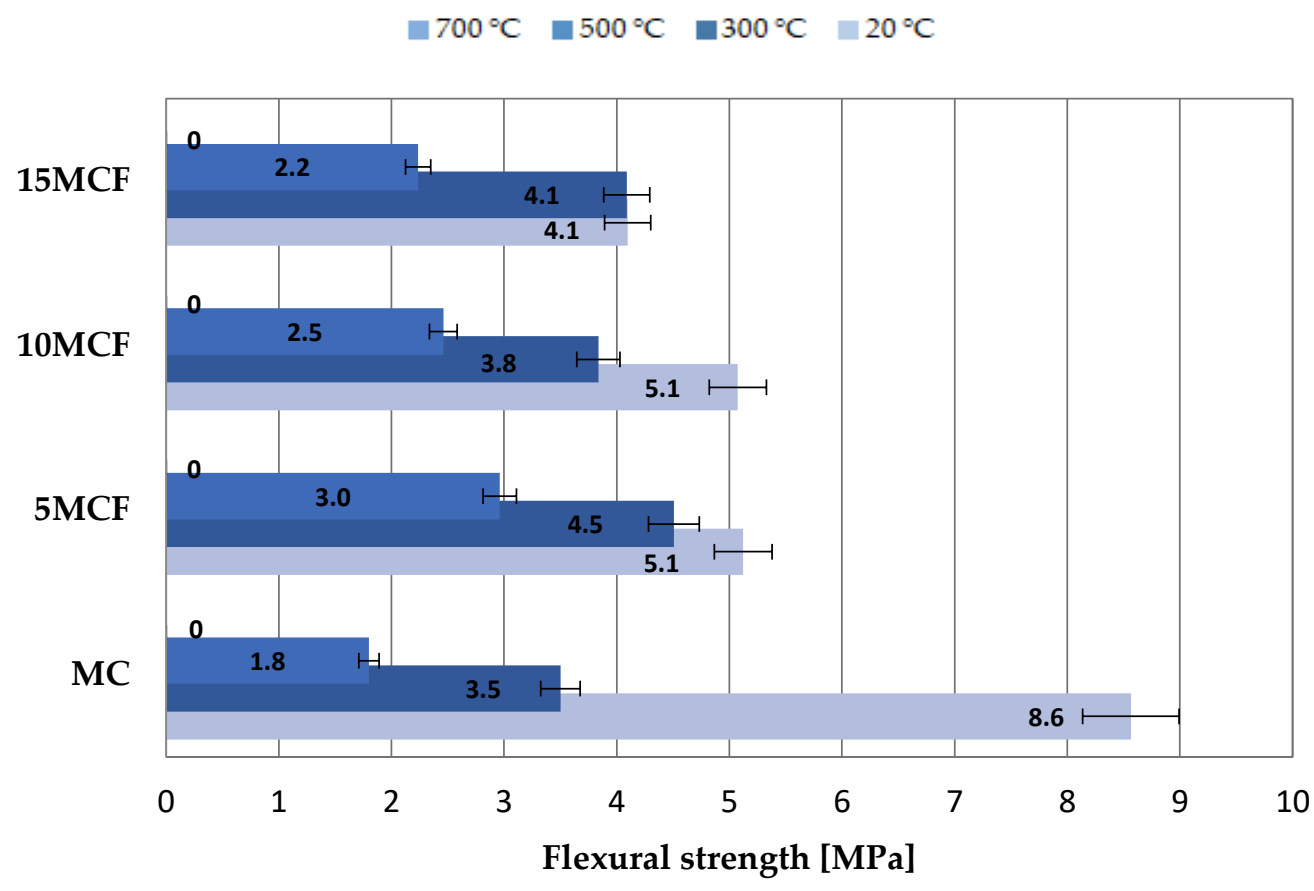

Figure 11. Average bending strength with error bars with a $5 \%$ value.

$700^{\circ} \mathrm{C}=500^{\circ} \mathrm{C}=300^{\circ} \mathrm{C}=20^{\circ} \mathrm{C}$

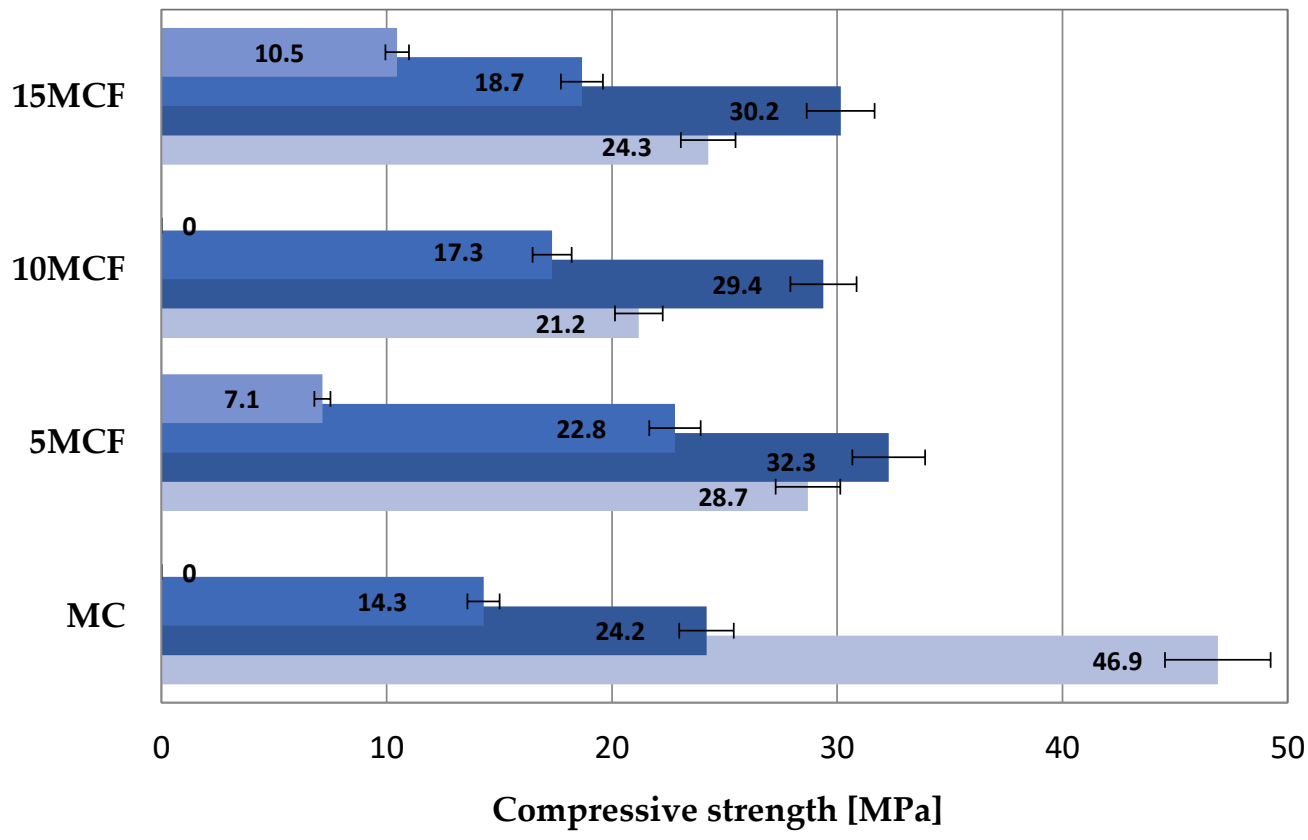

Figure 12. Average compressive strength with marked error bars with a $5 \%$ value. 
- MC $\square \mathrm{MCF} \triangle 10 \mathrm{MCF} \times 15 \mathrm{MCF} \longrightarrow$ Poly. (MC) - Poly. (5MCF)

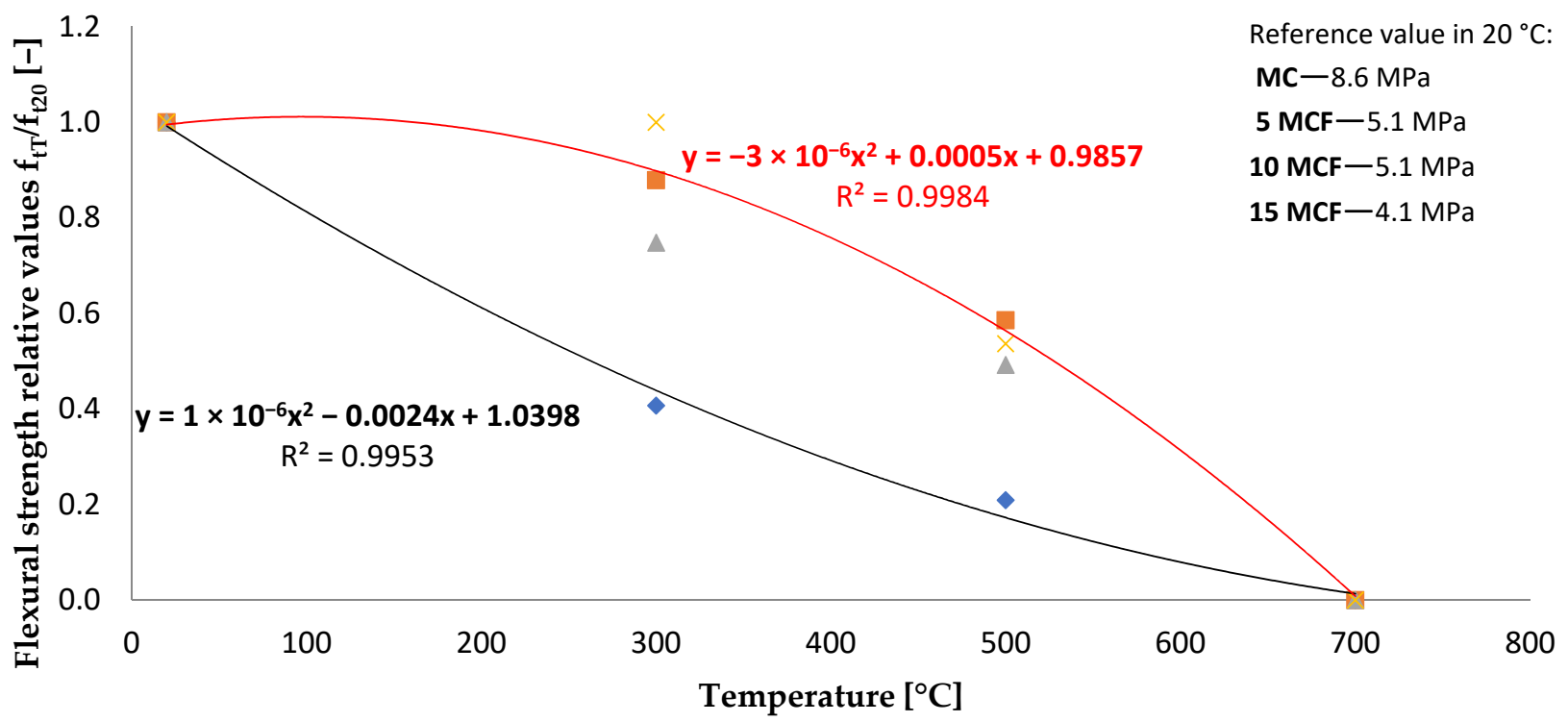

Figure 13. Flexural strength of heated fly ash: relative $f_{t T} / f_{t 20}$ values [-] with reference $f_{t T}$ values in $\mathrm{MPa}$.

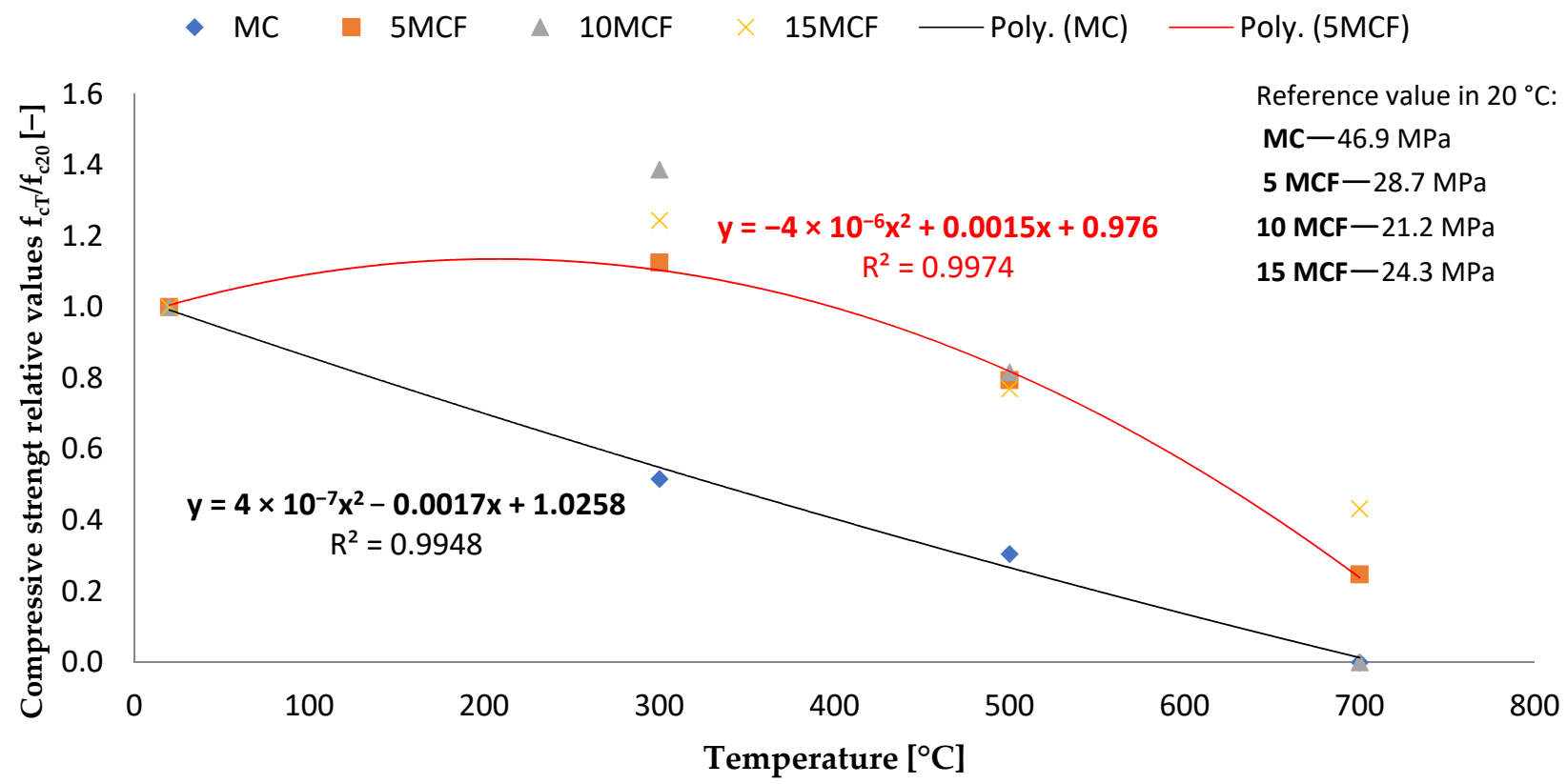

Figure 14. Changes in compressive strength for fly ash after thermal load: relative $f_{C T} / f_{C 20}$ values [-] with reference $\mathrm{f}_{\mathrm{cT}}$ values in $\mathrm{MPa}$. 


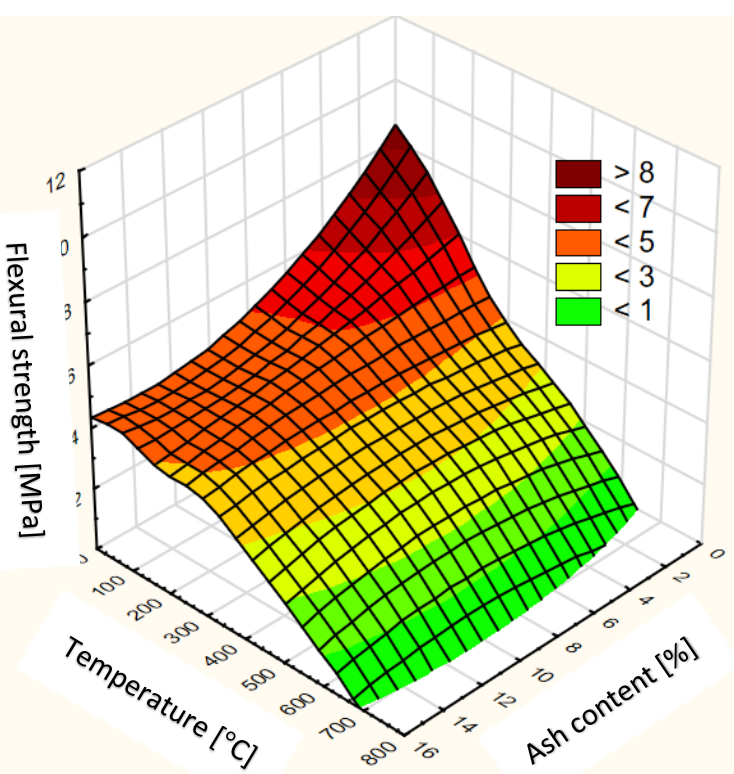

(a)

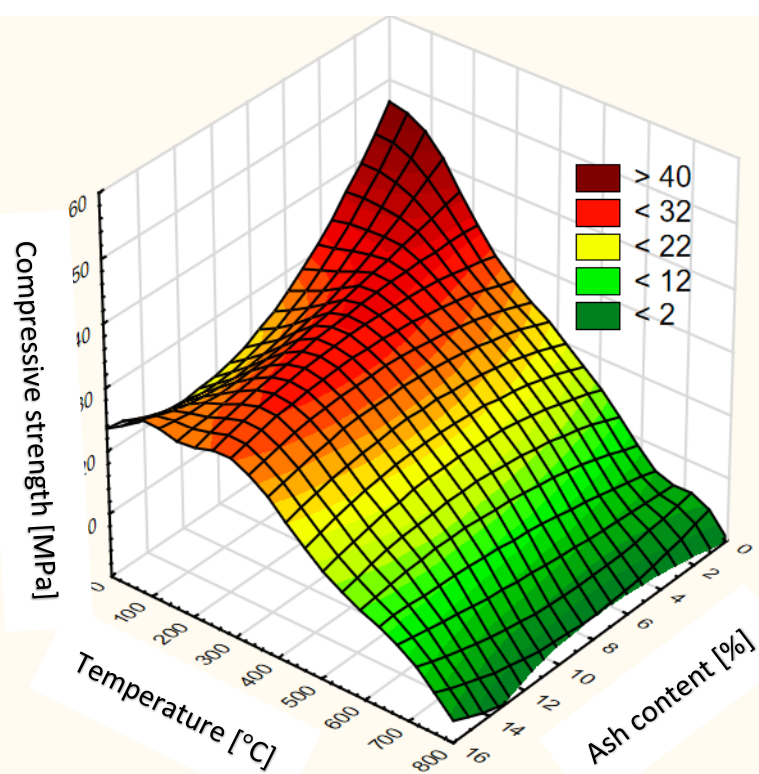

(b)

Figure 15. The surface diagram of heated cement mortars with the addition of fly ash: (a) Flexural strength; (b) Compressive strength.

Table 4. Summary of active automatic neural networks SANN.

\begin{tabular}{ccccc}
\hline & $\begin{array}{c}\text { Flexural } \\
\text { Strength Zeolite }\end{array}$ & $\begin{array}{c}\text { Compressive } \\
\text { Strength Zeolite }\end{array}$ & $\begin{array}{c}\text { Flexural } \\
\text { Strength } \\
\text { Fly Ash }\end{array}$ & $\begin{array}{c}\text { Compressive } \\
\text { Strength } \\
\text { Fly Ash }\end{array}$ \\
\hline Net. name & MLP 2-5-1 & MLP 2-9-1 & MLP 2-3-1 & MLP 2-3-1 \\
\hline $\begin{array}{c}\text { Training } \\
\text { performance }\end{array}$ & 0.965093 & 0.936999 & 0.922605 & 0.839214 \\
\hline $\begin{array}{c}\text { Test } \\
\text { performance }\end{array}$ & 0.960603 & 0960130 & 0.935012 & 0.884829 \\
\hline $\begin{array}{c}\text { Validation } \\
\text { performance }\end{array}$ & 0.993875 & 0.980009 & 0.798208 & 0.719528 \\
\hline Training error & 0.160101 & 8.360527 & 0.261530 & 12.64428 \\
\hline Test error & 0.175047 & 4.858383 & 0.246748 & 8.039583 \\
\hline Validation error & 0.055958 & 4.565156 & 0.351627 & 15.84463 \\
\hline $\begin{array}{c}\text { Training } \\
\text { algorithm }\end{array}$ & BFGS 191 & BFGS 117 & BFGS 28 & BFGS 30 \\
\hline Error function & SOS & SOS & SOS & SOS \\
\hline Error function & Tanh & Tanh & Exponential & Logistic \\
\hline Output ctivation & Exponential & Identity & Tanh & Logistic \\
\hline
\end{tabular}

\subsection{Properties of Cement Mortar with the Addition of Zeolite}

The average flexural strength was determined from 7 samples. The results are shown in Figure 16. The halves of the bars let us to determine the average compressive strength. The results are shown in Figure 17. Error bars are displayed for the selected plot series with a value of $5 \%$. 


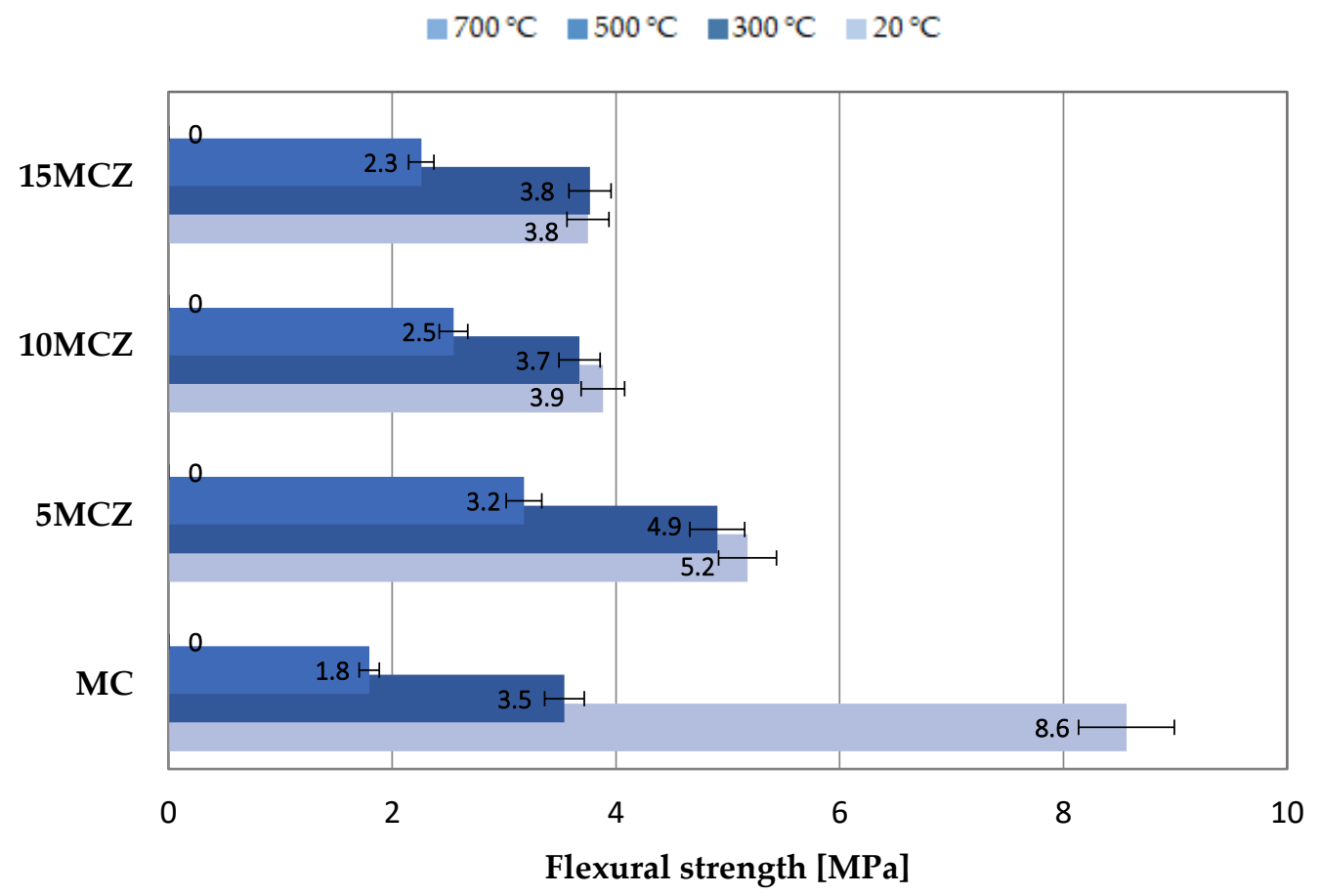

Figure 16. Average flexural strength with error bars marked with a 5\% value.

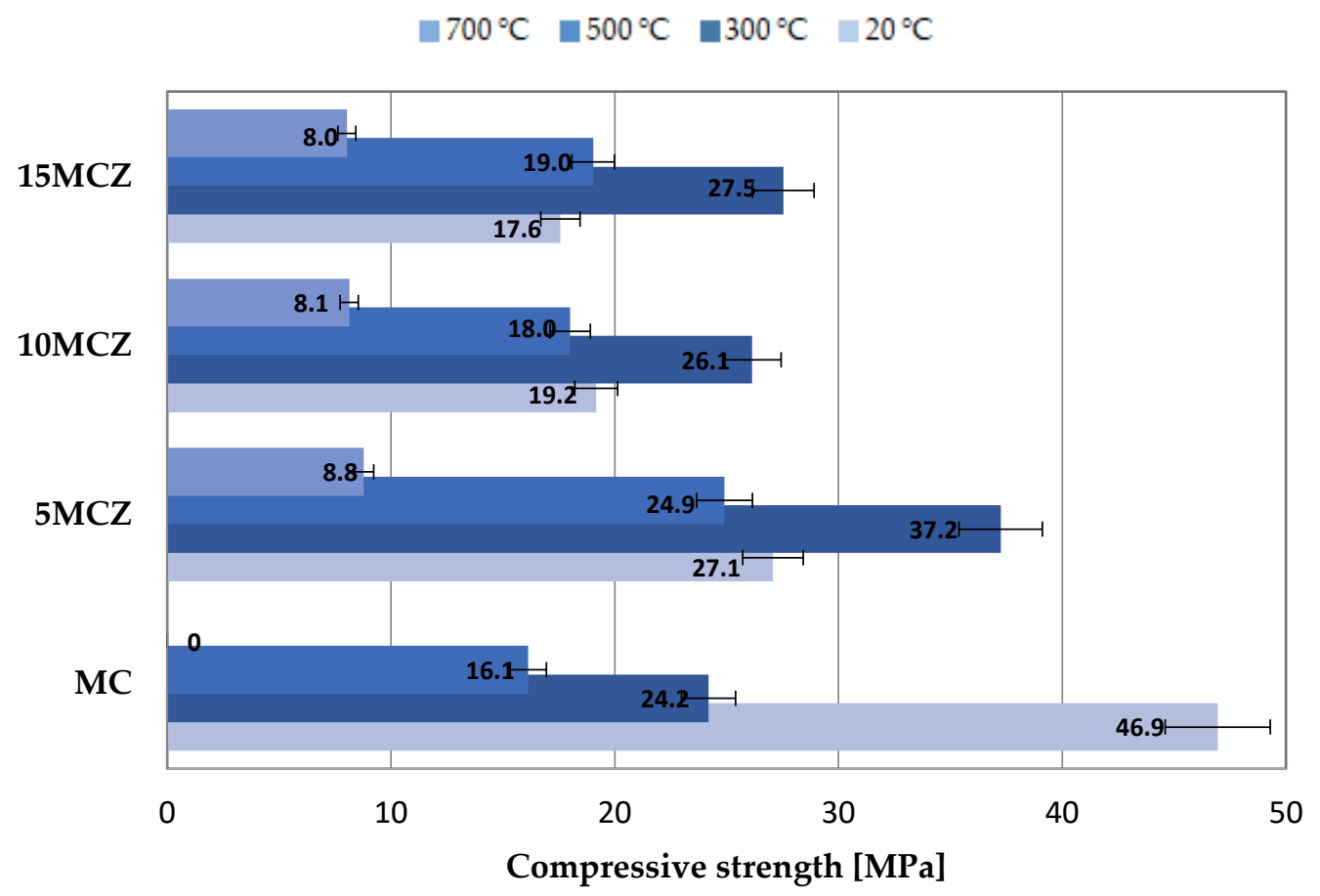

Figure 17. Average compressive strength with marked error bars with $5 \%$ value.

Taking into account the effect of $300{ }^{\circ} \mathrm{C}$ temperature, the highest values of flexural and compressive strength were demonstrated by the $5 \mathrm{MCZ}$ series samples containing a $5 \%$ zeolite supplement. These samples obtained a 40 and $54 \%$ increase in bending and compressive strength in relation to the base samples; also, at a temperature of $500{ }^{\circ} \mathrm{C}$, the $5 \mathrm{MCF}$ series samples achieved the highest values of bending and compressive strength. A 55\% increase in compressive strength and as much as $78 \%$ increase in bending strength was achieved. After annealing the samples at the temperature of $700{ }^{\circ} \mathrm{C}$, most of the samples were damaged, hence only partial results of the compressive strength. The obtained 
results confirm the positive effect of the addition of clinoptilolite in mortars exposed to high temperatures.

In the work of Czapik and Czechowicz [56], a relationship was found between the applied zeolite fraction and the increase in strength. Replacing $20 \%$ of the cement with the $0-0.500 \mathrm{~mm}$ zeolite fraction deteriorates the compressive strength of mortars even by $13 \%$. Using a fine-grained zeolite, e.g., $0-0.125$ or $0-0.063 \mathrm{~mm}$, the compressive strength can be improved by approx. $5-6 \%$. The finer zeolite, like silica dust, can better seal the mortar, filling the voids between cement grains and aggregate [57]. It reacts faster to the pozzolanic reaction due to the large specific surface area and small-volume grains. As a result, the CSH phase and compressive strength are increased. The addition of zeolite increases the strength parameters both in bending and compression. Mortars with zeolite fraction $0-0.063 \mathrm{~mm}$ are characterized by a fluid consistency, better compaction, which also favors the increase of strength because this process removes air pores [58].

Figures 18 and 19 show a comparison of the results of bending and compressive strength of the tested cement mortars. A significant increase of the factor by 1.6 was observed for the $15 \mathrm{MCZ}$ mortar heated at the temperature of $300{ }^{\circ} \mathrm{C}$.

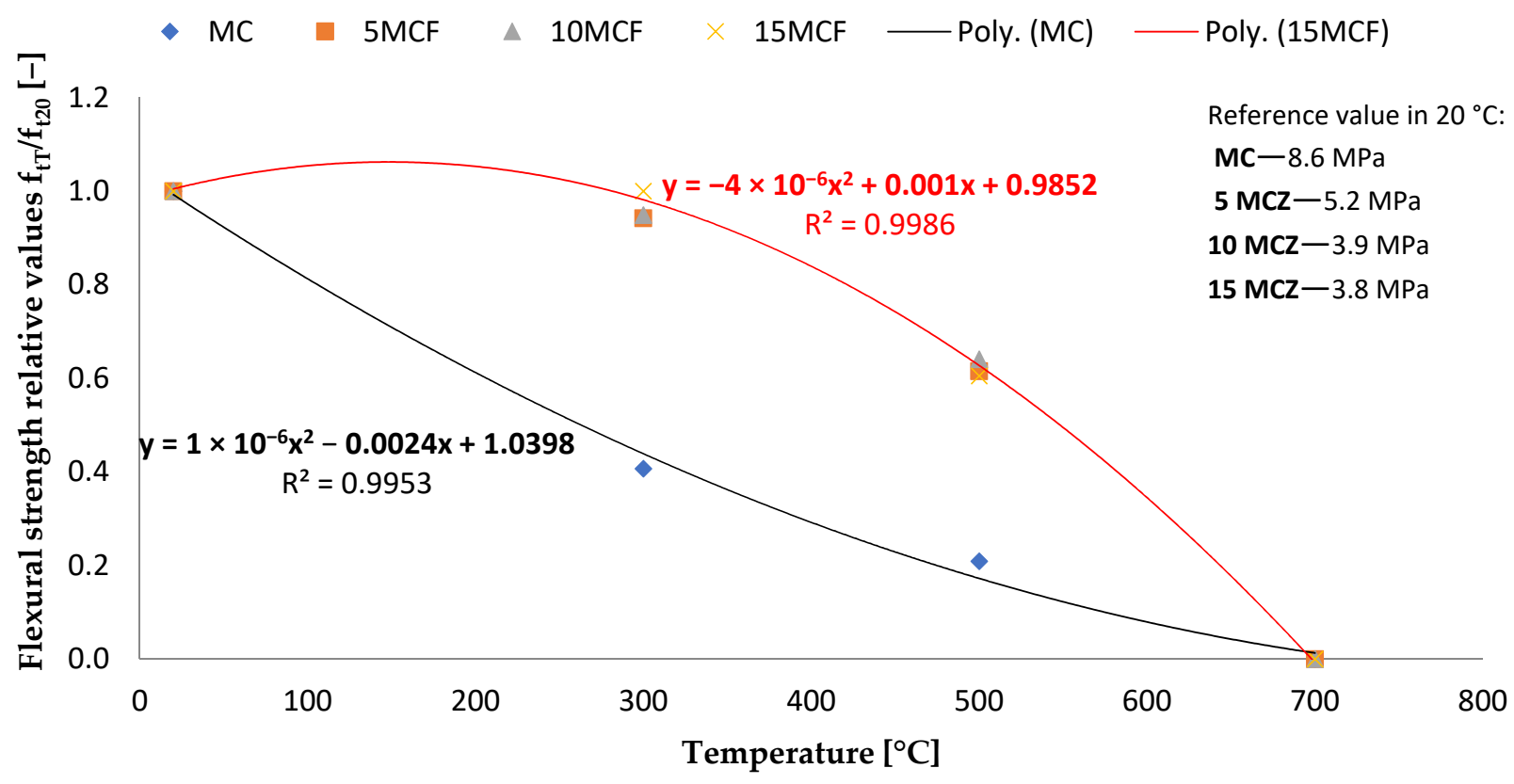

Figure 18. Flexural strength of heated zeolite: relative $f_{t T} / f_{t 20}$ values [-] with reference $f_{t T}$ values in $\mathrm{MPa}$.

Two prognostic models (flexural and compressive strength) were calculated by the method of automatic neural networks. Table 4 summarizes the calculation results of the SANN MPL 2-5-1 and MPL 2-9-1 models, which are correct prognostic models. The regression pattern is not generated. It is estimated that the correct regression model has been adopted (Figure 20).

To compare two different groups of observations, i.e., bending strength/compressive strength for ashes and zeolite, the t-Student's test was selected for independent trials. The accuracy of the adopted statistical model was determined at the significance level of $\alpha=0.05$.

The number of degrees of freedom was adopted as relationships between the studied groups. The group binding factors are: the amount of aggregate, the amount of water, and the amount of dusty fractions. For further calculations, $k=3$. degrees of freedom were assumed. The critical value for $\alpha=0.05$ and $k=3$ is 3.1824 . If the $t$-values calculated by the Student's $t$-test are greater than the critical value of 3.1824, the groups of results will differ from each other. 


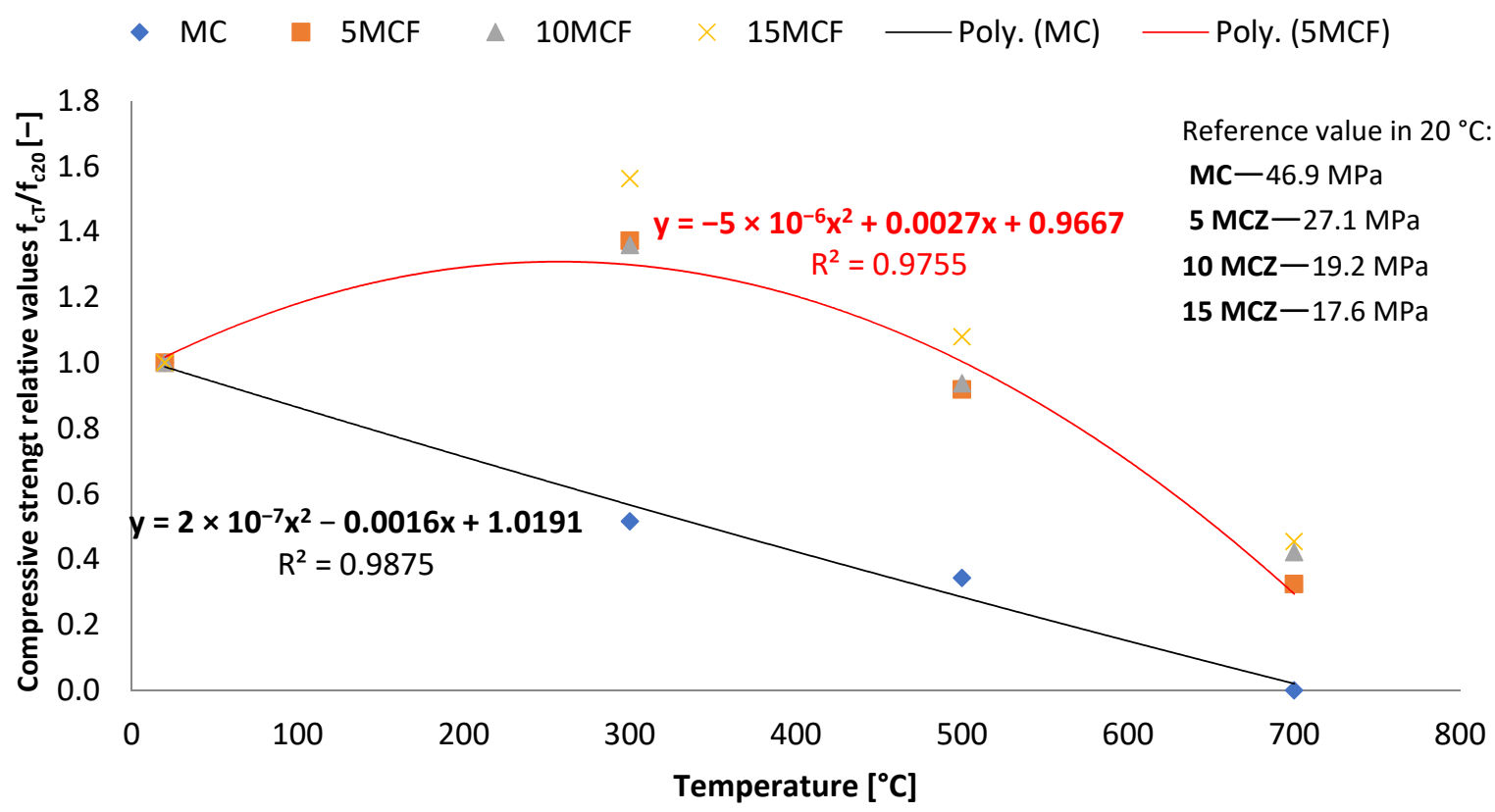

Figure 19. Changes in compressive strength for zeolite after thermal load: relative $f_{C T} / f_{C 20}$ values [-] with reference $\mathrm{f}_{\mathrm{cT}}$ values in $\mathrm{MPa}$.

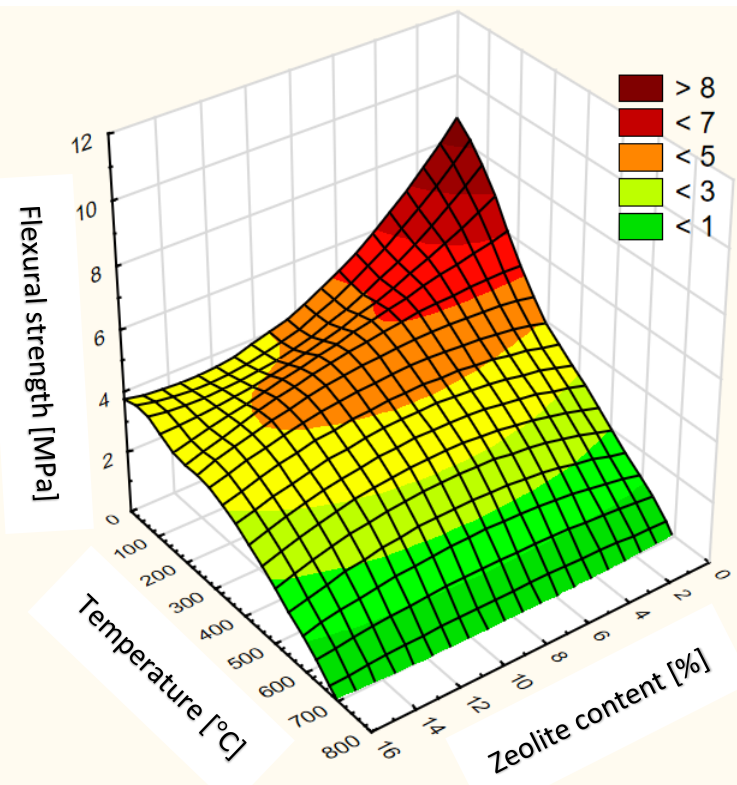

(a)

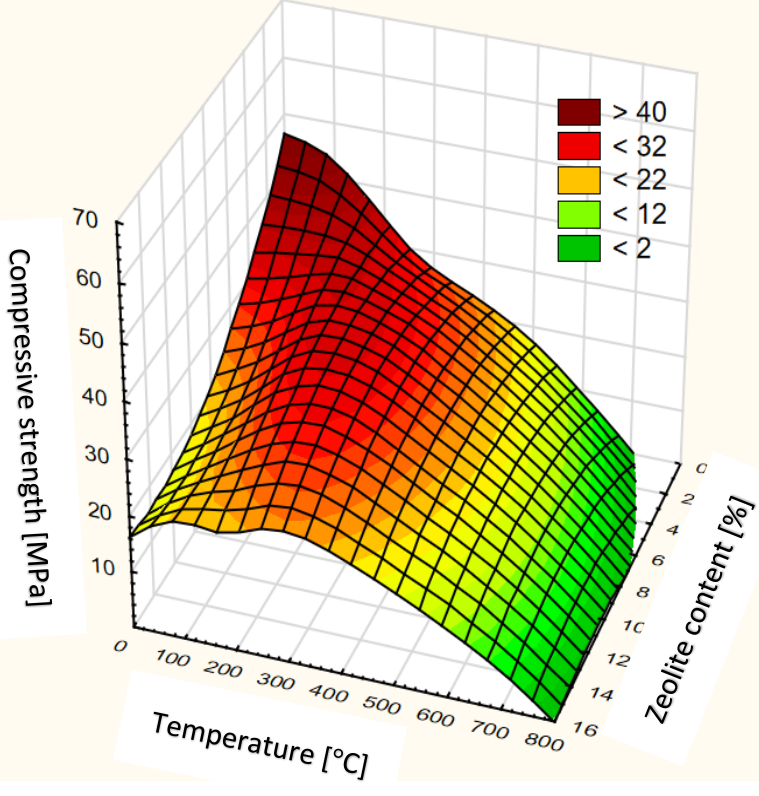

(b)

Figure 20. Surface chart of annealed cement mortars with the addition of zeolites: (a) Flexural strength; (b) Compressive strength.

After conducting the Student's $t$-test at the significance level of 0.05 , rejects the null hypothesis in favor of the alternative hypothesis. The obtained absolute values of $t$ in the Student's $t$-test are statistically significant and in each analyzed case, they assume values greater than the critical value of 3.1824-the studied groups of results differ from each other.

Table 5 shows the basic statistical characteristics. 
Table 5. Basic statistical characteristics of annealed cement mortars based on fly ash and zeolite.

\begin{tabular}{|c|c|c|c|c|c|c|}
\hline Group & $\begin{array}{c}\mathrm{N} \\
\text { Fly Ash }\end{array}$ & $\begin{array}{c}\mathbf{N} \\
\text { Zeolite }\end{array}$ & $\begin{array}{l}\text { Average } \\
\text { Fly Ash }\end{array}$ & $\begin{array}{l}\text { Average } \\
\text { Zeolite }\end{array}$ & $\begin{array}{c}\text { Standard } \\
\text { Deviation } \\
\text { Fly Ash }\end{array}$ & $\begin{array}{c}\text { Standard } \\
\text { Deviation } \\
\text { Zeolite }\end{array}$ \\
\hline $\begin{array}{l}20{ }^{\circ} \mathrm{C} \text { Flexural } \\
\text { strength [MPa] }\end{array}$ & 32 & 50 & 5.993750 & 5.346600 & 1.926849 & 2.000109 \\
\hline $\begin{array}{l}300^{\circ} \mathrm{C} \text { Flexural } \\
\text { strength }[\mathrm{MPa}]\end{array}$ & 58 & 50 & 3.997931 & 4.009600 & 0.680982 & 0.963796 \\
\hline $\begin{array}{l}500^{\circ} \mathrm{C} \text { Flexural } \\
\text { strength }[\mathrm{MPa}]\end{array}$ & 52 & 50 & 2.375192 & 2.474800 & 0.740788 & 0.720862 \\
\hline $\begin{array}{l}700{ }^{\circ} \mathrm{C} \text { Flexural } \\
\text { strength }[\mathrm{MPa}]\end{array}$ & 16 & 50 & 0.01000 & 0.001000 & 0.000000 & 0.000000 \\
\hline $\begin{array}{l}20{ }^{\circ} \mathrm{C} \text { Compressive } \\
\text { strength [MPa] }\end{array}$ & 32 & 50 & 31.69813 & 27.66280 & 11.30021 & 11.81927 \\
\hline $\begin{array}{c}300{ }^{\circ} \mathrm{C} \text { Compressive } \\
\text { strength [MPa] }\end{array}$ & 58 & 50 & 29.20034 & 29.11460 & 5.49422 & 7.73902 \\
\hline $\begin{array}{c}500{ }^{\circ} \mathrm{C} \text { Compressive } \\
\text { strength }[\mathrm{MPa}]\end{array}$ & 52 & 50 & 18.47406 & 19.73794 & 4.65435 & 4.91354 \\
\hline $\begin{array}{c}700{ }^{\circ} \mathrm{C} \text { Compressive } \\
\text { strength }[\mathrm{MPa}]\end{array}$ & 16 & 50 & 7.0288 & 6.33884 & 4.66019 & 4.04958 \\
\hline
\end{tabular}

\section{Conclusions}

The conducted research experiment confirmed the possibility of using an additive in the form of fly ash in the production of cement mortars, obtained from the thermal transformation of sewage sludge or zeolite. The obtained results and their analyzes allowed for the formulation of the following final conclusions:

1. The ashes used to prepare the cement mixture has a positive effect on its compressive strength. The mortar with 5 and $10 \%$ ash content reached the strength of about $5 \mathrm{MPa}$.

2. The physicochemical composition and pozzolanic activity of ashes from the thermal transformation of sewage sludge are different compared to fly ashes from hard coal combustion and does not meet the requirements for high furnace ashes. The highest percentage of the ash samples were oxides of silicon, calcium, phosphorus, and aluminum. The sum of the $\mathrm{SiO}_{2}, \mathrm{Al}_{2} \mathrm{O}_{3}$ and $\mathrm{Fe}_{2} \mathrm{O}_{3}$ in these ashes was 32.2, 6.3, and $19.3 \%$, respectively.

3. The high content of phosphorus compounds significantly affects the binding properties of cement mortars prepared with fly ash from municipal sewage sludge. The share of the tested additives in the mixture delays the beginning of setting and hinders its workability.

4. It should be clearly emphasized that, along with the increase in the annealing temperature during all the tests carried out, the strength of cement mortar samples decreases. The bending strength determined on samples with a $5 \%$ addition of ash and zeolite, heated at $300{ }^{\circ} \mathrm{C}$, is approx. $5 \mathrm{MPa}$.

5. During the heating of the samples at the temperature of $700{ }^{\circ} \mathrm{C}$, most of the tested mortars were destroyed, which made it impossible to determine their bending and compressive strength. The exception is mortars with the addition of fly ash in the amount of $5 \%$ during the compressive strength tests as well as with the addition of zeolite in the range of $5-15 \%$, also during the compressive strength tests.

6. The compressive strength determined for the mortar with $5 \%$ zeolite addition is about $13 \%$ higher than that determined for the mortar with ash. 
Author Contributions: Conceptualization, G.R., P.O., J.S., M.Ż., A.P. and A.B.; methodology, P.O., G.R., J.S., M.Ż. and A.P.; validation, P.O., G.R. and A.P.; formal analysis, A.P. and J.S.; investigation, A.P., J.S. and M.Ż.; resources, G.R. and M.Ż.; data curation, P.O., J.S., A.P., M.Ż. and G.R.; writingoriginal draft preparation, A.P. and G.R.; writing-review and editing, A.P. and P.O.; visualization, A.P., J.S. and M.Ż.; supervision, P.O.; project administration, J.S.; funding acquisition, P.O. and G.R. All authors have read and agreed to the published version of the manuscript.

Funding: This research was funded by the National Center for Research and Development as part of the project entitled A training simulator in the use of technical fire protection systems supporting the evacuating of people from buildings contract number DOB-BIO9/16/01/2018.

Institutional Review Board Statement: Not applicable.

Informed Consent Statement: Informed consent was obtained from all subjects involved in the study.

Data Availability Statement: The data presented in the study are publicly available at the Institute of Safety Engineering of the Main School of Fire Service, 52/54 Słowackiego Street, 01-629 Warsaw, Poland.

Acknowledgments: All individuals included in this section have consented to the acknowledgement.

Conflicts of Interest: The authors declare no conflict of interest.

\section{References}

1. BIBM-Federation of the European Precast Concrete Industry. What is Concrete? Available online: https://bibm.eu/precastconcrete/what-is-concrete (accessed on 20 October 2019).

2. Puertas, F.; García-Díaz, I.; Barba-Juan, A.; Gazulla, M.F.; Palacios, M.; Gómez-Tena, M.P.; Martinez-Ramirez, S. Ceramic wastes as alternative raw materials for Portland cement clinker production. Cem. Concr. Compos. 2008, 30, 798-805. [CrossRef]

3. Cement-Tracking Clean Energy Progress; IEA: Paris, France, 2019. Available online: https://www.iea.org/reports/trackingindustry / cement (accessed on 6 March 2020).

4. Deja, J.; Antosiak, B. Degree of progress of the fly ash reaction in alkali-activated fly-ash binders. Cem. Lime Concr. 2012, 17, 67-76.

5. MHURD. Ministry of Housing and Urban-Rural Development of the People's Republic of China Statistical Yearbook 2017. 2017. Available online: http:/ / www.mohurd.gov.cn (accessed on 6 March 2020).

6. Zhang, Z.; Zhang, L.; Yin, Y.; Liang, X.; Li, A. The recycling of incinerated sewage sludge ash as a raw material for $\mathrm{CaO}_{-} \mathrm{Al}_{2} \mathrm{O}_{3}-$ $\mathrm{SiO}_{2}-\mathrm{P}_{2} \mathrm{O}_{5}$ glass-ceramic production. Environ. Technol. 2015, 36, 1098-1103. [CrossRef]

7. Mininni, G.; Blanch, A.; Lucena, F.; Berselli, S. EU policy on sewage sludge utilization and perspectives on new approaches of sludge management. Environ. Sci. Pollut. Res. 2015, 22, 7361-7374. [CrossRef] [PubMed]

8. Yang, G.; Zhang, G.M.; Wang, H.C. Current state of sludge production, management, treatment and disposal in China. Water Res. 2015, 78, 60-73. [CrossRef]

9. Strategy for Dealing with Municipal Sewage Sludge for 2019-2022; Ministry of the Environment: Warsaw, Poland, 2018. Available online: https: / / www.gov.pl (accessed on 22 November 2021). (In Polish)

10. Uliasz-Bocheńczyk, A.; Mazurkiewicz, M.; Mokrzycki, E. Fly ash from Energy production-A waste, by product and raw material. Miner. Resour. Manag. 2015, 31, 139-150. Available online: http:/ / docplayer.pl/37695556-Fly-ash-from-energy-production-awaste-byproduct-and-raw-material.html (accessed on 12 November 2021).

11. Kepys, W.; Piotrowski, Z.; Wisła-Walsh, E. Investigation of the effect of lumpy ashes from municipal waste incineration on the properties of ash-water suspensions. Min. Geoeng. 2005, 29, 63-72.

12. Piotrowski, Z.; Uliasz-Bocheńczyk, A. Possibilities of economic utilization of waste from fluidized bed boilers. Miner. Resour. Manag. 2008, 24, 73-85.

13. The Waste Act of December 14, 2012 (Dz.U. 2013, Poz. 21). Available online: https:/ / isap.sejm.gov.pl (accessed on 25 April 2021).

14. Directive of the European Parliament and of the Council of November 14, 2010 on Industrial Emissions (Integrated Pollution Prevention and Control). 2010/75/UE. Available online: https:/ / eur-lex.europa.eu (accessed on 26 October 2021).

15. Regulation of the Minister of the Environment of 9 December 2014 on Waste Catalogs (Dz.U. 2014, Poz. 1923). Available online: http: / /isap.sejm.gov.pl (accessed on 12 October 2021).

16. Wzorek, Z. Recovery of Phosphorus Compounds from Thermally Processed Waste and Their Use as a Substitute for Natural Phosphorus Raw Materials; Chemical Engineering and Technology Series; PK Publishing House: Cracow, Poland, 2008.

17. Xu, H.; He, P.; Gu, W.; Wang, G.; Shao, L. Recovery of phosphorus as struvite from sewage sludge ash. Res. J. Environ. Sci. 2012, 24, 1533-1538. [CrossRef]

18. Donatello, S.; Cheeseman, C.R. Recycling and recovery routes for incinerated sewage sludge ash (ISSA): A review. Waste Manag. 2013, 33, 2328-2340. [CrossRef]

19. Weigand, H.; Bertau, M.; Hübner, W.; Bohndick, F.; Bruckert, A. RecoPhos: Full-scale fertilizer production from sewage sludge ash. Waste Manag. 2013, 33, 540-544. [CrossRef] [PubMed]

20. Wainwright, P.J.; Cresswell, D.J.F. Synthetic aggregates from combustion ashes using an innovative rotary kiln. Waste Manag. 2001, 21, 241-246. [CrossRef] 
21. Borowski, G. Assessment of suitability of vitrification of sewage sludge for their management. Prot. Environ. Nat. Resour. 2012, 51, 78-84.

22. Cyr, M.; Coutand, M.; Clastres, P. Technological and environmental behavior of sewage sludge ash (SSA) in cement-based materials. Cem. Concr. Res. 2007, 37, 1278-1289. [CrossRef]

23. Monzó, J.; Payá, J.; Borrachero, M.V.; Girbés, I. Reuse of sewage sludge ashes (SSA) in cement mixtures: The effect of SSA on the workability of cement mortars. Waste Manag. 2003, 23, 373-381. [CrossRef]

24. Pietrzyk, J. The role of thermal processes in the disposal of sewage sludge. In Proceedings of the Cracow Conference of Young Scholars, Cracow, Poland, 27-29 September 2012.

25. Merino, I.; Arévalo, L.F.; Romero, F. Preparation and characterization of ceramic products by thermal treatment of sewage sludge ashes mixed with different additives. Waste Manag. 2007, 27, 1829-1844. [CrossRef] [PubMed]

26. Krępys, W.; Pomykała, R.; Pietrzyk, J. Study of The Properties of the Ash-Water Suspension of the Incinerated Sewage Sludge Ash (Issa). Miner. Eng. 2014, 15, 205-212. Available online: https://www.researchgate.net/publication/292105547_Study_of_the_ properties_of_the_ash-Water_suspension_of_the_incinerated_sewage_sludge_ash_Issa (accessed on 15 October 2021).

27. Baeza-Broton, F.; Garces, P.; Paya, J.; Saval, J.M. Portland cement systems with addition of sewage sludge ash. Application in concretes for the manufacture of blocks. J. Clean. Prod. 2014, 82, 112-124. [CrossRef]

28. Chang, F.C.; Lin, J.D.; Tsai, C.C.; Wang, K.S. Study on cement mortar and concrete made with sewage sludge ash. Water Sci. Technol. 2010, 62, 1689-1693. [CrossRef]

29. Chen, M.; Blanc, D.; Gautier, M.; Mehu, J.; Gourdon, R. Environmental and technical assessments of the potential utilization of sewage sludge ashes (SSAs) as secondary raw materials in construction. Waste Manag. 2013, 33, 1268-1275. [CrossRef]

30. Suchorab, Z.; Barnat-Hunek, D.; Franus, M.; Łagód, G. Mechanical and Physical Properties of Hydrophobized Lightweight Aggregate Concrete with Sewage Sludge. Materials 2016, 9, 317. [CrossRef] [PubMed]

31. Qu, F.; Li, W.; Tao, Z.; Castel, A.; Wang, K. High temperature resistance of fly ash/GGBFS-based geopolymer mortar with load-induced damage. Mater. Struct. 2020, 53, 111. [CrossRef]

32. Khan, M.S.; Prasad, J. Fly ash concrete subjected to thermal cyclic loads. Fatigue Fract. Eng. Mater. Struct. 2010, 33, 276-283. [CrossRef]

33. Ortega, E.A.; Cheeseman, C.; Knight, J.; Loizidou, M. Properties of alkali-activated clinoptilolite. Cem. Concr. Res. 2000, 30, 1641-1646. [CrossRef]

34. Janotka, I.; Krajci, L. The properties of mortar using blends with Portland cement clinkier, zeolite tuff and gypsum. Ceram. Silik. 1995, 39, 81-120.

35. Dołżyk-Szypcio, K. Stress-dilatancy relationship for railway ballast. Stud. Geotech. Mech. 2018, 40, 79-85. [CrossRef]

36. Naiqian, F.; Hongwei, J.; Enyi, C. Study on the suppression effect of natural zeolite on expansion of concrete due to alkali-aggregate reaction. Mag. Concr. Res. 1998, 50, 17-24. [CrossRef]

37. Szulej, J.; Ogrodnik, P. The impact of zeolite tuffs as the cement supplement on the environment and selected dynamic and material properties. In Proceedings of the 2nd International Conference on the Sustainable Energy and Environmental Development (SEED'17), Cracow, Poland, 14-17 November 2017.

38. Franus, W.; Wdowin, M. Removal of ammonium ions by selected natural and synthetic zeolites. Miner. Resour. Manag. 2010, 26, 133-148.

39. Vrjmrlková, E.; Keppert, M.; Ondráček, M.; Černý, R.E. Effect of natural zeolite on the properties of high performance concrete. Cem. Lima Concr. 2013, 3, 150-159.

40. Grabowska, E.; Małolepszy, J. Effect of binder containing clinoptilolite on resistance of mortars to sulphate attack. Cem. Lima Concr. 2016, 2, 106-111.

41. PN-EN 197-1:2012; Cement-Part 1: Composition, Requirements and Compliance Criteria for Common Cements. Polish Committee for Standardization: Warsaw, Poland, 2012.

42. PN-EN 12390-5:2019-08; Concrete Tests-Part 5: Bending Strength of Test Specimens. Polish Committee for Standardization: Warsaw, Poland, 2019.

43. PN-EN 1363-1:2020-07; Fire Resistance Tests-Part 1: General Requirements. Polish Committee for Standardization: Warsaw, Poland, 2020.

44. Stefańczyk, B. General Construction. Building Materials and Products; Arkady: Warsaw, Poland, 2006; Volume 1, pp. 424-428.

45. Powęzka, A.; Ogrodnik, P.; Szulej, J.; Pecio, M. Glass Cullet as Additive to New Sustainable Composites Based on Alumina Binder. Energies 2021, 14, 3423. [CrossRef]

46. Powęzka, A.; Szulej, J.; Ogrodnik, P. Reuse of Heat Resistant Glass Cullet in Cement Composites Subjected to Thermal Load. Materials 2020, 13, 4434. [CrossRef] [PubMed]

47. Williams, P.T. Waste Treatment and Disposal, 2nd ed.; John Wiley \& Sons: Chichester, UK, 2005.

48. Tkaczewska, E. Properties of cements containing different grain fractions of siliceous fly ash. Roads Bridges 2008, 4, 47-80.

49. Rutkowska, G. Fly ash from thermal treatment of sewage sludge as an additive to ordinary concretes. Acta Sci. Pol. Archit. 2020, 19, 93-104. [CrossRef]

50. Szponder-Kołakowska, D.; Trybalski, K. Modern Methods and Measuring Devices in Examining the Properties of Raw Materials and Mineral Waste; AGH Publishing House: Cracow, Poland, 2014.

51. Wdowin, M.; Franus, W. Analysis of fly ashes in terms of obtaining earth rare elements from them. Energy Univ. Technol. 2014, 17, 369-380.

52. Tkaczewska, E.; Kłosek-Wawrzyn, E. Effect phosphate of $\mathrm{PO}_{4}{ }^{3-}$ ions on cement hydration. Cem. Lime Concr. 2012, 6, 401-408. 
53. PN-EN 451-2:2017-06; Fly Ash Test Method-Part 2: Determination of Fineness by Wet Sieving. Polish Committee for Standardization: Warsaw, Poland, 2017.

54. PN-EN 1097-07:2008; Tests for Mechanical and Physical Properties of Aggregates-Part 7: Determination of Filler DensityPycnometric Method. Polish Committee for Standardization: Warsaw, Poland, 2008.

55. Czapik, P.; Czechowicz, M. Effects of Natural Zeolite Particle Size on the Cement Paste Properties. Structure. Available online: https:/ / sae.tu.kielce.pl (accessed on 27 December 2021).

56. Kurdowski, W. Chemistry of Cement and Concreto; SPC: Cracow, Poland, 2010.

57. Nevill, A.M. Properties of Concreto; SPC: Cracow, Poland, 2012.

58. Powęzka, A.; Szulej, J.; Ogrodnik, P. Effect of high temperatures on the impact strength of concrete based on recycled aggregate made of heat-resistant cullet. Materials 2020, 13, 465. [CrossRef] [PubMed] 